\title{
A questão da teleologia nos apontamentos do jovem Nietzsche: Zu Schopenhauer e Zur Teleologie (1867-68)*
}

\author{
William Mattioli**
}

\begin{abstract}
Resumo: Este artigo corresponde à primeira de duas partes que perfazem um estudo sobre a questão da teleologia nos apontamentos do jovem Nietzsche entre 1867 e 1869. No seu todo, o trabalho pretende oferecer uma leitura de três conjuntos de notas escritos pelo filósofo nesse período: Zu Schopenhauer, Zur Teleologie e Vom Ursprung der Sprache, com um claro enfoque nas notas sobre a teleologia, de 1868. Meu objetivo é tentar mostrar que, apesar das diversas críticas de Nietzsche à teleologia e de sua aparente adesão (via Lange) ao darwinismo, sua posição é melhor compreendida como um tipo de vitalismo, que é receptivo à ideia de uma intencionalidade inconsciente na natureza, mas que recusa explicitamente a concepção antropomorficamente inflacionada de um designer divino. Nesta primeira parte do estudo, me dedico a uma análise do texto $\mathrm{Zu}$ Schopenhauer e de parte do conjunto de notas reunidas sob o título Zur Teleologie.
\end{abstract}

Palavras-chave: Nietzsche, teleologia, intencionalidade, natureza, inconsciente.

\footnotetext{
* Este artigo corresponde em grande medida aos dois primeiros capítulos de minha tese de doutorado: $\mathrm{O}$ inconsciente no jovem Nietzsche. Da intencionalidade das formas naturais à vida da linguagem (2016). O texto aqui apresentado, porém, contém acréscimos e modificações substanciais ao texto da tese. Uma segunda parte deste estudo sobre a questão da teleologia nas notas do jovem Nietzsche será publicada em breve como continuação do aqui exposto. $\mathrm{O}$ artigo correspondente levará o título: "Natureza, vida e finalismo nas Notas sobre a teleologia e Sobre a origem da linguagem de Nietzsche (1868-69)".

** Professor da Universidade Federal do Rio de Janeiro, Rio de Janeiro, RJ, Brasil. Correio eletrônico: william.mattioli@gmail.com
} 
Mattioli, W.

\section{Introdução}

Entre os anos de 1867 e 1869, isto é, entre o período final dos seus anos de formação e o início de sua carreira como professor de filologia na Universidade de Basel, Nietzsche redigiu três importantes conjuntos de notas que, apesar de possuírem escopos de análise distintos, revelam uma certa continuidade temática. Essa continuidade diz respeito, sobretudo, ao desenvolvimento de algumas questões que perpassam esses apontamentos e que nos ocuparão no presente trabalho. Os três conjuntos de notas aos quais nos referimos são aqueles reunidos respectivamente sob os títulos: Zu Schopenhauer, ${ }^{1}$ Zur Teleologie ${ }^{2}$ e Vom Ursprung der Sprache. ${ }^{3}$ Dentre as questões que perpassam esses textos se destacam as seguintes: os limites do materialismo, a relação entre naturalismo e teleologia, o problema da individuação e da origem do intelecto e a pergunta pela natureza do organismo. Se quisermos ainda determinar um fio condutor que atravessa todas essas questões, podemos dizer que se trata do problema mais geral da teleologia, ou, em outras palavras, da questão acerca do finalismo ou da intencionalidade na natureza. Não espero que a determinação deste tópico como um tópico comum a todas aquelas questões seja considerada de antemão como algo autoevidente. Pretendo, antes, poder esclarecê-la ao longo deste trabalho, que se dedicará a uma breve análise do texto $Z u$ Schopenhauer e de parte do conjunto de notas reunidas sob o título Zur Teleologie. A análise conjunta do restante das notas sobre a teleologia e do texto sobre a origem da linguagem será feita em outro artigo, que constituirá a segunda parte deste estudo.

1 Escritos entre 1867 e 1868 e publicados em KGW I/4, pp. 418-430.

2 As notas para a dissertação planejada por Nietzsche sobre a teleologia se encontram em KGW I/4, pp. 549-578 e correspondem aos Fragmentos póstumos 62 [3] - 62 [57] de abril/maio de 1868.

3 Texto concebido como introdução ao curso de gramática latina oferecido por Nietzsche em Basel em 1869-70 e publicado em KGW II/2, pp. 185-188.

78 | Cad. Nietzsche, Guarulhos/Porto Seguro, v.39, n.3, p. 77-119, setembro/dezembro, 2018. 
A questão da teleologia nos apontamentos do jovem Nietzsche: $\mathrm{Zu}$...

Uma vez que acredito poder encontrar na questão da teleologia e da intencionalidade na natureza o fio condutor que liga aqueles três textos e que determina, direta ou indiretamente, o desenvolvimento das questões elencadas acima, nada mais natural do que dedicar a maior parte de nossa discussão ao texto que trata especificamente deste problema, qual seja, o conjunto de notas que leva o título "Sobre a teleologia" ou "O conceito do orgânico a partir de Kant", de 1868. A título de síntese introdutória, podemos dizer que, nestas notas - escritas sob o impacto da leitura de Lange, em especial de sua discussão sobre o darwinismo e a teleologia -, Nietzsche, em consonância com a posição do autor da História do materialismo, parece rejeitar a interpretação teleológica da natureza, proposta por Kant como princípio heurístico para dar conta da particularidade dos fenômenos orgânicos, e aceitar a explicação mecânica oferecida pela teoria da evolução de Darwin. Mesmo que essa aceitação não seja inequívoca, uma vez que o texto confronta diversas posições e por vezes parece contestar que seja possível fornecer uma explicação epistemicamente satisfatória com base meramente em forças mecânicas, a tese mais sobressalente e que mais parece indicar uma tomada de posição por parte de Nietzsche é a tese anti-teleológica associada ao darwinismo.

Em artigo recém-publicado, Ricardo Dalla Vecchia (2016) se debruça sobre essas notas e, seguindo as interpretações de Toscano (2001) e Lopes (2008), conclui que a posição assumida por Nietzsche corresponde a uma rejeição da concepção teleológica em favor de um materialismo crítico que reconhece o caráter meramente regulativo dos conceitos científicos. Dalla Vecchia (2016, p. 239) identifica nessa posição um tipo de "proto-perspectivismo", 4 na medida em que ela assume que todo nosso aparato conceitual, do átomo dos materialistas ao conceito teleológico de causa final, tem um caráter ficcional e

4Swift (2005, p. 80) aponta igualmente a presença de uma forma de perspectivismo já nessas notas de juventude.

Cad. Nietzsche, Guarulhos/Porto Seguro, v.39, n.3, p. 77-119, setembro/dezembro, 2018. 
Mattioli, W.

funciona como mero regulador de nossas atividades cognitivas e de nossa vida como um todo, não sendo capaz de satisfazer qualquer ambição correspondencialista. A não ser por algumas diferenças nos detalhes, essa é, grosso modo, a interpretação proposta pela grande maioria dos comentadores que se dedicaram a analisar as posições assumidas pelo jovem Nietzsche no debate suscitado pelo confronto entre as descobertas trazidas pela teoria da evolução de Darwin e as concepções mais tradicionais da teleologia. ${ }^{5} \mathbf{O}$ texto de Toscano, que foi republicado, com pequenas alterações, em seu livro The Theatre of Production. Philosophy and Individuation between Kant and Deleuze (2006), talvez seja o exemplo mais bem elaborado e mais sofisticado dessa abordagem. Toscano argumenta em favor da tese de que há em Nietzsche uma recusa de qualquer forma de teleologia e aponta para a assunção de uma posição que pretende responder à pergunta pela emergência da representação em termos não-representacionais.

Com relação à interpretação da Dalla Vecchia, concordo com a tese de que a posição de Nietzsche pode ser entendida como um tipo de ficcionalismo. Que esse ficcionalismo tenha como pano de fundo a assunção de um materialismo crítico nos moldes de Lange e, consequentemente, uma rejeição integral da teleologia com base nas premissas do darwinismo, me parece uma interpretação unilateral. Minha discussão destas notas tentará mostrar, ao contrário, que não devemos sobrestimar a suposta adesão de Nietzsche (via Lange) à explicação mecanicista e ao darwinismo nesse momento. A questão central com a qual pretendo me confrontar é se podemos ver a produtividade da natureza, que Nietzsche tentará compreender mediante o conceito de

5 Essa leitura é defendida por Toscano (2001 e 2006), Swift (2005), Cruz (2015), Himmelmann (2017); de forma um pouco confusa e um tanto quanto frágil por Gentili (2010); com alguma nuance, é defendida também por Solies (2014) e Emden (2014); no Brasil, é defendida por Dalla Vecchia (2016) e, também com alguma nuance, por Lopes (2008). Três exceções importantes a essa abordagem hegemônica são Crawford (1988), Hill (2003) e Miller (2006), que buscam, cada um a seu modo, relativizar as críticas de Nietzsche à teleologia e mostrar que não há, de sua parte, uma adesão exclusivista ao modelo de explicação do materialismo.

80| Cad. Nietzsche, Guarulhos/Porto Seguro, v.39, n.3, p. 77-119, setembro/dezembro, 2018. 
A questão da teleologia nos apontamentos do jovem Nietzsche: Zu...

"força vital" (Lebenskraft), como uma atividade perpassada por um certo tipo de intencionalidade. ${ }^{6}$ Dado o teor das notas e a forma como os conceitos são manipulados por Nietzsche nesse momento, a resposta mais direta a essa pergunta talvez fosse "não". Contudo, uma análise mais atenta aos detalhes e às ambiguidades concernentes a este ponto em particular nos revela um horizonte mais amplo e mais receptivo à tese de que há um tipo singular de intencionalidade inconsciente agindo nas forças produtivas da natureza.

A interpretação destes apontamentos apresentada no presente estudo se baseia em três estratégias de leitura: 1) a indicação de certas ambiguidades do texto, tendo em vista demonstrar que a suposta rejeição da teleologia é na verdade a rejeição de um tipo específico de raciocínio teleológico, a saber, aquele parasitado por concepções teológicas e que fornece a base para a físico-teologia; 2) uma confrontação com as fontes de Nietzsche, em especial Lange e Schopenhauer, tendo em vista elucidar o uso de alguns conceitos e algumas expressões e localizar melhor sua posição no debate; e 3)

6 "Intencionalidade" deve ser entendido aqui como a capacidade de se ter um "objeto" ou um "algo" em vista, isto é, um estado em que algo é "visado", que se caracteriza por "estar dirigido a algo" ou "ser acerca de algo", o que Dennett (1996, p. 35), entre outros, chama de "aboutness". Esse traço específico de estados mentais está certamente presente em intenções, no sentido comum do termo, mas não deve ser reduzido a isso. Na medida em que se refere fundamentalmente ao ato de estar direcionado a um objeto, essa noção se confunde, em alguma medida, com a noção de "representação", que está certamente pressuposta em qualquer forma de "intenção" ou "interesse". É possível perceber, nas últimas décadas, um crescente interesse numa retomada crítica de modelos teleológicos, acompanhada de um extenso debate em torno da relação entre aspectos funcionais na biologia, o conceito de finalidade e a necessidade ou não de se pressupor alguma forma de intencionalidade para uma compreensão adequada da estrutura de sistemas orgânicos e biológicos em geral. Muitas das posições assumidas contemporaneamente neste debate partem de um confronto direto com as teses de Kant na terceira Crítica, sobretudo em razão das suas potencialidades para uma delimitação adequada do complexo de problemas envolvidos numa retomada crítica de modelos teleológicos. Para um panorama geral deste debate, cf. Illetterati e Michelini 2008; para um panorama geral das recentes discussões em torno da teoria da biologia de Kant, cf. Goy e Watkins 2014. No caso de Nietzsche, a maior parte da discussão sobre este tema se concentra em seus textos de maturidade, nos quais ele busca elaborar suas teses em torno das noções de vontade de potência e de perspectivismo. Dentro desse contexto, ele parece assumir uma noção deflacionada de conformidade a fins, na medida em que, de acordo com suas teses, todo querer e todo interpretar é sempre um querer-algo e um interpretar-algo, ou seja, possui uma estrutura minimamente teleológica, pois está direcionado a um "fim" ou tem "algo visado" (cf. Stack 1983, p. 246s., Richardson 1996, p. 21, Solomon 2002, p. 67s.).

Cad. Nietzsche, Guarulhos/Porto Seguro, v.39, n.3, p. 77-119, setembro/dezembro, 2018. 
Mattioli, W.

uma contextualização destas notas no conjunto dos apontamentos do período - os apontamentos sobre Schopenhauer, escritos imediatamente antes, e o texto sobre a origem da linguagem, escrito cerca de um ano depois -, com o intuito de mostrar que a rejeição de qualquer tipo de intencionalidade na natureza vai de encontro às teses defendidas nesses dois outros textos. Mas neste artigo, que, como indicado, corresponde à primeira parte do estudo, analisarei apenas a relação entre as notas sobre a teleologia e os apontamentos sobre Schopenhauer; o texto sobre a origem da linguagem será analisado no artigo correspondente à segunda parte.

\section{O problema da origem do intelecto nos apontamentos sobre Schopenhauer (1867-68)}

Quando, pouco tempo após seu primeiro encontro com Schopenhauer, o jovem Nietzsche se volta para a metafísica da vontade de seu mentor intelectual tendo em vista esclarecer para si certos problemas ali presentes, aquele se destaca parece ser a tentativa de Schopenhauer de compatibilizar a teoria transcendental kantiana acerca das funções de nosso aparato cognitivo com uma narrativa naturalista de sua gênese a partir do desenvolvimento de formas orgânicas complexas. Mas esse problema é retraduzido por nosso autor nos termos de uma questão que me parece ainda mais fundamental: a dos "limites da individuação" (Nachlass/FP 57 [55], KGW I/4.422). Vinculado a esta questão se encontra uma outra, que remete diretamente ao paradoxo inerente à tentativa de compatibilização entre transcendentalismo e naturalismo aludido acima: o problema da "origem do intelecto" (Nachlass/FP 57 [61], KGW I/4.429).

O núcleo duro da crítica de Nietzsche é, de modo geral, o mesmo daquela crítica que se tornou clássica sob o nome de "paradoxo de Zeller" e que constitui uma antinomia identificada pelo próprio Schopenhauer em seu sistema, à qual ele deu o nome de "antinomia

82 | Cad. Nietzsche, Guarulhos/Porto Seguro, v.39, n.3, p. 77-119, setembro/dezembro, 2018. 
A questão da teleologia nos apontamentos do jovem Nietzsche: Zu...

da nossa faculdade de conhecimento" (Schopenhauer 2005, p. 76). ${ }^{7}$ Se temos em vista o que é dito por Nietzsche nesses apontamentos de juventude, podemos dizer que a metafísica do segundo livro do Mundo como vontade e representação, em particular a explicação teleológica da morfologia envolvida nas manifestações da vontade, torna a epistemologia do primeiro livro inócua, se não a falsifica inteiramente. Com efeito, em sua consideração teleológica da natureza, Schopenhauer procura oferecer uma teoria acerca da gênese do intelecto que o localiza num estágio tardio da evolução dos organismos, remetendo-o a uma função do cérebro. $\mathrm{O}$ intelecto é visto como uma ferramenta da vontade com um fim determinado: a satisfação das necessidades mais elevadas de organismos cada vez mais complexos. Por outro lado, em sua teoria transcendental do conhecimento, o intelecto é visto como a fonte das formas da individuação: tempo, espaço e causalidade, através das quais unicamente é possível pensar o caráter processual do desenvolvimento dos seres orgânicos. É somente por intermédio dessas formas subjetivas que o mundo como representação que conhecemos existe. Mas essa teoria transcendental da individuação, à qual a epistemologia evolucionista do livro II deveria servir de complemento, inviabiliza de antemão qualquer narrativa naturalista acerca da gênese do mecanismo de individuação, pois numa tal narrativa este mecanismo tem que ser pressuposto em todos os estágios de desenvolvimento anteriores ao aparecimento do intelecto (que, segundo a epistemologia transcendental, é a própria fonte da individuação). ${ }^{8}$

7 Cf. sobre isso Cacciola 1994, p. 77 e Santos 2017. Esta parte do trabalho retoma as linhas gerais da argumentação elaborada em Mattioli 2013 e desenvolve de modo mais detalhado alguns pontos apenas mencionados ali.

8 Uma primeira formulação desta antinomia nos é apresentada ainda no livro I do primeiro volume do Mundo (Schopenhauer 2005, p. 75s.), quando Schopenhauer discute a lei de causalidade. Uma segunda formulação se encontra no segundo volume (Schopenhauer 2015, p. 331s.), no capítulo dedicado à consideração objetiva do intelecto, isto é, aquela que, partindo das relações e interações físicas, químicas e biológicas do mundo exterior, tem por fim colocar à mostra as condições empíricas mediante as quais se tornou possível e necessário o surgimento de um mecanismo cognitivo. É essa 
Mattioli, W.

Sob influência de Lange e, sobretudo, da leitura de um texto de Rudolf Haym sobre Schopenhauer, ${ }^{9}$ o jovem Nietzsche se debruçou sobre esse problema e identificou a questão acerca da origem do intelecto e dos limites da individuação como o paradoxo central da filosofia de seu mentor intelectual. Nos apontamentos que ora analisamos, o jovem filólogo se pergunta como uma vontade alheia ao princípio de razão (grundlos), alheia a qualquer atributo cognitivo (erkenntnislos) e atemporal (zeitlos) pode vir a se tornar fenômeno, manifestando-se em entes individuados. Posto de outro modo: “de onde [provém] o aparato representacional no qual a vontade aparece?" (Nachlass/FP 57 [55], KGW I/4.425)

Nietzsche observa que, em sua consideração da natureza orientada segundo as ciências etiológicas, na qual a natureza é vista como objetivação progressiva da vontade, Schopenhauer concebe uma gradação de fenômenos da vontade "com necessidades de existência cada vez maiores: para satisfazê-las, a natureza se serve de uma série gradual correspondente de meios, dentre os quais tem lugar o intelecto, desde a sensação mais incipiente até a sua extrema clareza." (Nachlass/ FP 57 [55], KGW I/4.425) Ora, nessa tese naturalista concernente aos graus de objetivação da vontade, a existência da individuação e de suas formas: tempo, espaço e causalidade é pressuposta antes do surgimento do intelecto. Sem elas, com efeito, é inconcebível qualquer desenvolvimento do orgânico. A consequência extraída daí por Nietzsche no contexto das teses defendidas por Schopenhauer é a seguinte: "numa tal concepção, um mundo fenomênico é colocado antes do mundo fenomênico: se quisermos manter os termos schopenhauerianos acerca da coisa em si. Já antes do aparecimento do intelecto vemos o

\footnotetext{
segunda formulação que se encontra explicitamente citada nas notas de Nietzsche (Nachlass/FP 57[61], KGW I/4.430). Há ainda uma terceira formulação presente no capítulo VI do livro II de Parerga e Paralipomena, "Sobre a filosofia e a ciência da natureza" (Schopenhauer 1911-1926, p. 150), que é também referida por Nietzsche (Nachlass/FP 57[55], KGW I/4.426). Discuto essas passagens de forma mais detalhada em Mattioli 2013, p. 83ss.

9 Cf. Barbera 1995; Lopes 2008, pp. 95-144; Langbehn 2005, pp. 121-133.
}

84 | Cad. Nietzsche, Guarulhos/Porto Seguro, v.39, n.3, p. 77-119, setembro/dezembro, 2018. 
A questão da teleologia nos apontamentos do jovem Nietzsche: Zu...

principium individuationis, a lei de causalidade, em plena efetividade." (Nachlass/FP 57 [55], KGW I/4.425 )

Não há nada de despropositado nessa consequência extraída por Nietzsche das teses de Schopenhauer, que nos conduziriam a colocar um mundo do fenômeno antes do mundo do fenômeno e, consequentemente, a pressupor uma modalidade de individuação distinta de e anterior àquela rege a esfera de nossa representação. $\mathrm{Na}$ verdade, encontramos no próprio texto schopenhaueriano formulações que caminham justamente nessa direção. Leia-se, quanto a isso, o início do parágrafo 26 do primeiro tomo do Mundo, por exemplo. Após ter introduzido, no parágrafo anterior, o conceito de ideia e o definido como o "fixo e determinado grau de objetivação da vontade, na medida em que esta é coisa em si" (Schopenhauer 2005, p. 191), é no parágrafo 26 que Schopenhauer dá início à discussão acerca das manifestações de cada um desses graus segundo certas leis naturais, discussão que forma a base de sua filosofia da natureza e que conduzirá finalmente ao tema da teleologia, que ocupa os parágrafos 27 e 28.0 que nos interessa aqui é, sobretudo, o modo como ele, logo no início do parágrafo 26 , caracteriza aqueles graus de objetivação da vontade, que, em seu nível mais elementar, não são outra coisa que as forças naturais originárias: "tais forças são em si (an sich) fenômenos imediatos da vontade (unmittelbare Erscheinungen des Willens)" (Schopenhauer 2005, p. 192). Que as forças sejam em si fenômenos já é, de saída, uma formulação que exige de nós certo apelo ao princípio de caridade interpretativa. É preciso compreender que Schopenhauer está falando aqui de um tipo particular de fenômeno, um fenômeno originário, não submetido ao princípio de razão; apenas os "fenômenos particulares" daquelas forças estão submetidos a tal princípio, assim como os atos humanos particulares, ao contrário do agir humano em geral, igualmente um "fenômeno imediato da vontade". Ao falar dos "fenômenos particulares" das forças da natureza, logo após ter caracterizado essas forças mesmas como 
Mattioli, W.

"fenômenos imediatos da vontade", Schopenhauer está, sem o dizer, colocando um fenômeno anterior ao fenômeno, ainda que este primeiro fenômeno se encontre fora do tempo e do espaço e, portanto, fora do princípio de individuação tal como ele o havia definido no parágrafo 23 (Schopenhauer 2005, p. 171s.).

Mas se, por um lado, é verdade que aqueles fenômenos primeiros não estão submetidos ao princípio de razão e, portanto, se encontram para além do princípio de individuação na sua acepção explícita, não podemos deixar de notar, por outro lado, que as ideias ou graus de objetivação da vontade são determinados e individualizados entre si: a gravidade é uma força originária ou ideia; a impenetrabilidade é uma outra força ou ideia, assim como cada caractere humano, em sua essência, é individual e único. As ideias, portanto, são várias; há uma diversidade delas, distintas entre si. A necessidade de postular tais ideias como uma espécie dimensão intermediária entre a enorme heterogeneidade dos múltiplos fenômenos naturais e o caráter uno da vontade, a essência indivisível por trás de todos eles, conduz a um momento bastante delicado no interior do sistema. Como aponta Rufolf Malter (1991, p. 253), as ideias representam uma determinação individual, distinguem-se umas das outras segundo sua forma específica, mas ao mesmo tempo devem se encontrar fora do tempo e do espaço, âmbito no qual unicamente é possível a individuação. Ou seja, a princípio, às ideias não caberia nem distinção, nem pluralidade. É justamente nesse sentido que, ao elaborar mais detalhadamente o conceito de ideia já no livro III, ele diz que ela é a objetidade imediata e mais adequada da vontade; "é a própria coisa-em-si" (Schopenhauer 2005, p. 242), com a observação, porém, de que se trata aqui da coisa em si trazida sob a forma mais geral da representação: o ser-objeto para um sujeito.

Dentro desse contexto, é preciso notar que quando Nietzsche faz seguir à sua constatação de que, "numa tal concepção, um mundo fenomênico é colocado antes do mundo fenomênico", o adendo: "se

$86 \mid$ Cad. Nietzsche, Guarulhos/Porto Seguro, v.39, n.3, p. 77-119, setembro/dezembro, 2018. 
A questão da teleologia nos apontamentos do jovem Nietzsche: Zu...

quisermos manter os termos schopenhauerianos acerca da coisa em si", ele está se referindo justamente ao problema apontado por Rudolf Malter em seu comentário sobre o papel das ideias na filosofia da natureza de Schopenhauer: pode a essência ser determinada, e determinada segundo uma gradação hierárquica, sem com isso estar envolta na pluralidade? (cf. Malter 1991, p. 253) Quanto ao adendo de Nietzsche, ele se refere ao fato de que os predicados que Schopenhauer atribui à essência são retirados de uma contraposição à representação, de modo que tudo aquilo que pertence à dimensão da essência deve ser entendido como alheio às condições sob as quais a pluralidade é possível. A própria unidade da vontade é pensada em oposição ao conceito de unidade que determina como "uno" cada ser individuado dentro da pluralidade. Como algo que se encontra fora da individuação, a vontade se caracteriza por uma espécie de unidade incondicionada. O caráter problemático desta oposição é igualmente apontado por Malter (1991, p. 254) e, como seria de esperar, tampouco passou despercebido aos olhos de Nietzsche. Ele se refere explicitamente a este problema na seguinte passagem:

mais importante para nós é o fato de que também todos os predicados da vontade são tomados de empréstimo do mundo fenomênico. É verdade que Schopenhauer tenta aqui e ali apresentar o sentido destes predicados como inteiramente inapreensível e transcendente, por exemplo, em Mundo como vontade II p. 368: A unidade daquela vontade na qual reconhecemos a essência em si do mundo fenomênico é uma unidade metafísica, portanto, o conhecimento da mesma é transcendente, isto é, não repousa sobre as funções de nosso intelecto e por isso não pode ser efetivamente apreendida por estas. ${ }^{10}$ Porém, o sistema schopenhaueriano como um todo, e em particular a primeira apresentação do mesmo no volume 1 do Mundo como vontade, nos convence do seguinte: onde lhe é de algum modo conveniente, Schopenhauer se permite o uso humano e de modo algum transcendente da unidade na vontade. [...] Portanto, com essa "unidade" ocorre o mesmo

10 Passagem retirada do capítulo 25 do segundo tomo do Mundo (cf. Schopenhauer 2005, p. 389).

Cad. Nietzsche, Guarulhos/Porto Seguro, v.39, n.3, p. 77-119, setembro/dezembro, 2018. 
Mattioli, W.

que com a "vontade", trata-se de predicados da coisa em si retirados do mundo fenomênico. (Nachlass/FP 57 [55], KGW I/4.424)

Se nos voltarmos agora à questão em torno da origem da própria individuação, nos veremos diante do seguinte problema: a tese "oficial" de Schopenhauer responde à pergunta pela gênese da individuação remetendo-a às funções do intelecto, que percebe o mundo como um mundo de entidades individuadas no espaço; sua filosofia da natureza, contudo, remete a gênese do próprio intelecto ao desenvolvimento material das manifestações da vontade no mundo orgânico, o que já pressupõe não apenas o princípio de individuação e a lei de causalidade, mas também uma conformidade a fins, uma teleologia inerente ao processo evolutivo daquelas manifestações da vontade. A importância de chamar a atenção para o caráter teleológico deste processo reside em dois fatores: em primeiro lugar, toda a filosofia da natureza de Schopenhauer se baseia numa consideração teleológica dos fenômenos naturais em seu encadeamento hierárquico, dos graus mais baixos aos graus mais elevados de objetivação da vontade, que culmina na gênese do intelecto humano; em segundo lugar, encontramos no tratamento schopenhaueriano desta teleologia natural o mesmo paradoxo que habita sua consideração objetiva do intelecto. Em um ensaio de 1896, intitulado “Über die Zweckmäßigkeit in der Natur bei Schopenhauer", Otto Keutel resume o problema do seguinte modo: de acordo com o ponto de vista kantiano e idealista do primeiro livro, Schopenhauer afirma que a finalidade é introduzida na natureza pelo nosso intelecto; por outro lado, porém, o próprio intelecto é visto como resultado de um processo natural teleologicamente orientado: é a vontade que, nos graus mais elevados de sua objetivação, produz um intelecto para fins de conservação das formas orgânicas mais elevadas (Keutel 1896, p. 28). ${ }^{11}$

11 Lido com esse problema de forma mais detida em Mattioli 2018.

$88 \mid$ Cad. Nietzsche, Guarulhos/Porto Seguro, v.39, n.3, p. 77-119, setembro/dezembro, 2018. 
A questão da teleologia nos apontamentos do jovem Nietzsche: Zu...

Os problemas que emergem desse paradoxo são vários, e o que nos interesse aqui em especial é a impossibilidade de se explicar a produção material do intelecto (que Schopenhauer faz remontar a uma finalidade imanente ao desenvolvimento das formas de objetivação da vontade no mundo natural), uma vez que se tenha estabelecido a radical alteridade entre vontade e representação. Abordaremos esse ponto em mais detalhes no decorrer do trabalho, mas vale notar aqui que essa interpretação de Keutel é fundamentalmente inspirada nas críticas desenvolvidas por Adolf Trendelenburg em suas Investigações Lógicas (1862, p. 110ss.), e que são retomadas por Rudolf Haym em seu ensaio sobre Schopenhauer de 1864. Este ensaio de Haym, por sua vez, foi uma das principais fontes de Nietzsche para a composição de seus primeiros apontamentos críticos sobre Schopenhauer. Dada essa contextualização do problema, torna-se mais claro para nós o lugar ocupado por aquela que é, a meu ver, a pergunta central de Nietzsche nesses apontamentos, e que é apresentada em resposta à tentativa schopenhaueriana de solucionar o problema considerando a existência do mundo anterior ao surgimento do intelecto como uma "existência hipotética": ${ }^{2}$

Mas perguntemos [...] como foi alguma vez possível o surgimento do intelecto? A existência do último nível anterior ao aparecimento do intelecto é tão hipotética quanto a de todo nível precedente, isto é, ele não existiu, porque não existia nenhuma consciência. No nível subsequente, o intelecto deve então aparecer, ou seja, de um mundo não existente deve eclodir, repentina e imediatamente, a flor do conhecimento. Isso deve, ao mesmo tempo, ter ocorrido na esfera da atemporalidade e da a-espacialidade, sem mediação da causalidade: o que se origina a partir de um tal mundo

12 Cf. Nachlass/FP 57 [55], KGW I/4.426, onde Nietzsche cita a seguinte passagem dos Parerga: "os processos geológicos que precederam toda a vida sobre a Terra não estiveram presentes em nenhuma consciência: nem na própria, porque eles não têm nenhuma; nem em uma outra, porque não havia nenhuma. Portanto, eles não existiram, não eram absolutamente nada; ou, então, o que ainda significaria sua existência ali naquele momento? - No fundo, é uma existência meramente hipotética; a saber, se uma consciência tivesse existido naqueles tempos primordiais, tais processos teriam sido nela representados; é a isso que somos conduzidos pelo regressus dos fenômenos: portanto, na essência da coisa em si jazia sua potência para se manifestar em tais processos."

Cad. Nietzsche, Guarulhos/Porto Seguro, v.39, n.3, p. 77-119, setembro/dezembro, 2018. 
Mattioli, W.

desmundanizado tem de ser propriamente - segundo as declarações de Schopenhauer - coisa em si: ora, ou o intelecto jaz então eternamente fundido à coisa em si como um novo predicado, ou não pode haver intelecto, pois um intelecto jamais poderia ter vindo a ser. (Nachlass/FP 57 [55], KGW I/4.426)

$\mathrm{O}$ argumento de Nietzsche parte aqui da impossibilidade de se pensar uma emergência radical da representação a partir de uma dimensão absolutamente não-representacional. ${ }^{13}$ Se entendermos a vontade no sentido de Schopenhauer, como um impulso cego e atemporal, como uma instância absolutamente alheia à representação, a emergência de um existente capaz de experiência se torna inexplicável: não haveria um intelecto. Contudo, uma vez que há intelecto, Nietzsche conclui que "ele não pode ser um instrumento do mundo fenomênico, como quer Schopenhauer", mas, antes, tem de ser ele mesmo coisa em si, isto é, vontade (Nachlass/FP 57 [55], KGW I/4.427).

Ora, está claro que uma reconceitualização da vontade nesses termos vai de encontro ao dualismo fundamental de Schopenhauer entre vontade e representação. Com a noção de um intelecto que é imanente à vontade, estaríamos nos aproximando de uma forma de idealismo objetivo que é incompatível com sua intuição filosóficoexistencial mais essencial: seu pessimismo. ${ }^{\mathbf{1 4}}$

Dentro desse contexto, temos o seguinte cenário: ou a vontade é aquilo mesmo que representa (isto é, que possui em si a capacidade

13 Cf. sobre isso Hill 2003, p. 98.

14 Que Schopenhauer não pode abrir mão da tese do caráter não-representacional e não-cognitivo da vontade fica claro tão logo constatamos que dessa tese depende sua visão de mundo segundo a qual a vida é essencialmente sofrimento e o sofrimento provém da vontade (Malter 1983, p. 450). Caso a vontade comportasse qualidades intencionais, cognitivas e representacionais, o sofrimento não estaria mais metafisicamente fundamentado, pois o caráter de negatividade do mundo provém justamente do fato de que a vontade é um impulso irracional, inconsciente e cego. Que o mundo seja um vale de lágrimas se explica, segundo a tese de Schopenhauer, pelo fato de que "o princípio de sua existência é expressamente sem fundamento (grundlos), a saber, uma cega vontade de vida [...], pois somente uma vontade absolutamente cega poderia colocar-se a si mesma na situação na qual nos vemos." (MVR II, p. 691) Sobre isso, cf. ainda Mattioli 2013, p. 93, e também Gardner 1999, p. 383.

$90 \mid$ Cad. Nietzsche, Guarulhos/Porto Seguro, v.39, n.3, p. 77-119, setembro/dezembro, 2018. 
A questão da teleologia nos apontamentos do jovem Nietzsche: Zu...

de representação), ou não pode haver representação, pois esta jamais poderia ter origem. Nietzsche retoma esta aporia novamente nos fragmentos de 1870: "Mas de onde [provém] a representação? Eis o enigma. Naturalmente [ela existe] desde o início, ela jamais pode ter se originado." (Nachlass/FP 5 [80], 1870-1871, KSA 7.113)

Pode-se concluir que, com base numa constatação dos paradoxos do voluntarismo de Schopenhauer no que concerne à origem da representação e aos limites da individuação, o jovem Nietzsche é conduzido a uma revisão de alguns dos pressupostos básicos que moldavam a compreensão schopenhaueriana da relação entre vontade, natureza, representação e consciência, pressupostos que o próprio Schopenhauer não estava disposto a abandonar. Essa revisão aponta para um ultrapassamento do quadro teórico do idealismo subjetivo kantiano ao qual Schopenhauer permanecia vinculado, uma vez que, nesse novo cenário teórico esboçado por Nietzsche, os limites da representação são expandidos indeterminadamente. Com essa expansão, um novo transcendentalismo entra em cena, vinculado agora, podemos dizer, a uma forma de idealismo objetivo.

Para tentar esclarecer um pouco melhor este ponto, lembremos em que se baseia a crítica central de Nietzsche presente nos apontamentos sobre Schopenhauer. Para ele, o grande problema da tentativa schopenhaueriana de conciliar idealismo subjetivo e narrativa evolucionista é que a origem do intelecto e, consequentemente, da representação e da individuação, se tornara ininteligível. O que está em perigo aqui é a possibilidade mesma de se pensar de modo consistente a dimensão transcendental, uma vez que o transcendental é identificado, em Schopenhauer, com o processo genético de individuação (o que nos permite falar em uma teoria genéticotranscendental da individuação). ${ }^{15}$ Ora, o modo como Schopenhauer opera a disjunção entre a dimensão pré-individual e o domínio da individuação, isto é, negando qualquer aspecto representacional no

15 Cf. Langbehn 2005, p. 98.

Cad. Nietzsche, Guarulhos/Porto Seguro, v.39, n.3, p. 77-119, setembro/dezembro, 2018. 
âmbito da vontade, acaba por solapar as bases mesmas do processo de individuação. Com isso, o próprio transcendental é solapado. ${ }^{\mathbf{1 6}}$ As críticas de Nietzsche, por sua vez, apontam para uma solução que visa salvaguardar o aspecto transcendental do voluntarismo por meio de um ultrapassamento do idealismo subjetivo ao qual Schopenhauer permanecia vinculado. Isso se dá mediante um deslocamento do transcendental de seu locus subjetivo (encarnado na consciência individual) para o plano transsubjetivo, transpessoal e inconsciente da vontade. ${ }^{17}$

Dentro desse novo cenário teórico, podemos dizer que o desenvolvimento dos organismos engendrará o surgimento da consciência, como um atributo tardio e acidental da representação, ${ }^{18}$ mas o predicado do intelecto (ou daquilo que podemos qualificar de modo menos específico como processos intencionais e mecanismos representacionais) deve estar pressuposto desde o início, como uma forma de cognição inconsciente atuando em cada ato da vontade e constituindo uma dimensão de objeto.

De acordo com essas reflexões, a filosofia da natureza de Schopenhauer, com seus componentes naturalistas e teleológicos, na medida em que depende da tese de um desenvolvimento gradual das formações orgânicas, só pode ser legitimada no horizonte do transcendentalismo se o quadro do idealismo subjetivo kantiano for abandonado. $\mathrm{O}$ surgimento de um complexo aparato cognitivo como

16 Cf. Toscano 2001, p. 46.

17 É interessante notar aqui que esse ultrapassamento do quadro teórico com o qual Schopenhauer permanecia comprometido e a consequente reformulação do conceito de vontade que advém desse movimento é o que fornece as primeiras bases para o que virá a se configurar muitos anos depois como uma complexa teoria dos impulsos e que será articulada em torno da hipótese das vontades de potência. Um dos aspectos centrais dessa hipótese é a atribuição de intencionalidade à pluralidade de forças que dão forma aos fenômenos em geral. É essa atribuição de intencionalidade que dá suporte à tese, vastamente debatida na literatura secundária, segundo a qual toda pulsão percebe, realiza valorações, assume perspectivas e interpreta.

18 A tese de que a consciência é tão somente um acidente da representação será claramente apresentada por Nietzsche no aforismo 357 de $A$ gaia Ciência.

92 | Cad. Nietzsche, Guarulhos/Porto Seguro, v.39, n.3, p. 77-119, setembro/dezembro, 2018. 
A questão da teleologia nos apontamentos do jovem Nietzsche: $\mathrm{Zu}$...

o cérebro no seio da natureza depende da existência de mecanismos intencionais-representacionais temporalmente determinados atuando inconscientemente no âmbito da vontade e constituindo assim uma dimensão de objeto (mesmo que precisemos considerar esses mecanismos como extremamente primitivos). ${ }^{19}$ Assim, se quisermos compreender a filosofia da natureza de Schopenhauer, com sua orientação a um só tempo científica e teleológica, como um momento de seu pensamento que ainda tem lugar numa forma da transcendentalismo, devemos estar dispostos a abrir mão daquele dualismo metafísico estrito entre vontade e representação e restituir à vontade sua contrapartida intencional (cognitiva).

\section{Schopenhauer e o problema da origem do intelecto nas notas sobre a teleologia (1868)}

Se, de acordo com o que foi dito acima, a questão acerca da origem do intelecto é a questão norteadora principal dos apontamentos sobre Schopenhauer, não é nenhuma surpresa que ela ocupe um lugar fundamental também nas notas sobre a teleologia, escritas praticamente no mesmo período. Numa passagem dessas notas que considero fundamental, Nietzsche diz que "a teleologia lança uma série de questões que são insolúveis ou que não foram solucionadas até agora" (Nachlass/FP 62 [13], KGW I/4.553). O exemplo dado por ele é justamente a questão da origem do intelecto. Para nossa análise, é digno de nota o fato de que ele retoma aqui o problema fundamental que o havia ocupado nos apontamentos sobre Schopenhauer. Como dito no início deste trabalho, acredito haver uma importante continuidade de temas entre esses textos, e um desses temas (talvez o mais relevante) é justamente a questão acerca dos limites da individuação e da origem do intelecto. Ao associar o tema da teleologia à questão sobre a origem

19 Em seus comentários sobre a metafísica da vontade de Schopenhauer, Schmidt observa de modo bastante instrutivo as dificuldades inerentes à explicação do surgimento de uma matéria sensitiva em formas de vida evolutivamente superiores (Schmidt 1977, p. XXI, em especial nota 67, p. XLII).

Cad. Nietzsche, Guarulhos/Porto Seguro, v.39, n.3, p. 77-119, setembro/dezembro, 2018. 
Mattioli, W.

do intelecto, Nietzsche abre uma nova perspectiva para a abordagem do problema que não estava explícita nos apontamentos de Leipzig. Apesar de não ser desenvolvida de modo mais detalhado nas notas, essa perspectiva se mostra bastante produtiva ao nos debruçarmos sobre as ambiguidades do voluntarismo de Schopenhauer no tocante à teleologia e à origem metafísica do mundo como representação, temas centrais de sua filosofia da natureza.

Antes de mais nada, é preciso salientar que, apesar de Schopenhauer insistir no caráter não cognitivo da vontade, ele se vale de um vocabulário inteiramente intencionalista ao descrever os mecanismos psíquicos mobilizados por ela na manifestação dos seus atos. Isso fica claro sobretudo no âmbito das análises psicológicas presentes no capítulo 19 do segundo tomo do Mundo, que leva o título: "Do primado da vontade na consciência de si" (Schopenhauer 2015, p. $243 \mathrm{ss}$.). Ali, somos confrontados com formulações que atribuem à vontade a capacidade de sentir inclinação e interesse com relação a determinadas representações e aversão e desinteresse com relação a outras, além da capacidade de decisão, de conhecimento e de direcionamento do intelecto (Schopenhauer 2015, p. 252s.). ${ }^{20}$ Pode-se argumentar, é verdade, que esse aspecto concerne somente à dimensão imanente de nossa vida psíquica e pulsional. Isso equivaleria a dizer que a estrutura de nossos atos volitivos (conscientes e inconscientes) é marcada por uma orientação a um determinado fim, o que não significa que possamos atribuir uma finalidade à dimensão do querer em sua totalidade e, consequentemente, às objetivações da vontade como um todo. É o que está dito na seguinte passagem do parágrafo 29 do primeiro tomo do Mundo: "a vontade sempre sabe o que quer aqui e agora, mas nunca o que quer em geral. Todo ato isolado tem um fim; o querer como um todo não." (Schopenhauer 2005, p. 231) Por conseguinte, prossegue Schopenhauer, as forças que se manifestam nos fenômenos da natureza não possuem uma finalidade em si. "De

20 Para uma discussão mais detalhada deste ponto, cf. Mattioli 2013, p. 72s.

94 Cad. Nietzsche, Guarulhos/Porto Seguro, v.39, n.3, p. 77-119, setembro/dezembro, 2018. 
A questão da teleologia nos apontamentos do jovem Nietzsche: Zu...

fato, a ausência de todo fim e limite pertence à essência da vontade em si, que é um esforço sem fim." (Schopenhauer 2005, p. 230) Com isso, Schopenhauer nega qualquer tipo de instância cognitiva (intencional) agindo segundo fins na produção das formas naturais.

Entretanto, ao abordar o processo de evolução das formas naturais que culminará na produção material do intelecto, isto é, na origem da representação, ele se vale de uma argumentação profundamente teleológica que parece pressupor igualmente um tipo de intencionalidade, mas que não é não redutível à dimensão dos atos isolados das vontades empíricas. À pergunta acerca do que teria levado a natureza a produzir algo como um aglomerado orgânico dotado de capacidades cognitivas, Schopenhauer responde recorrendo à tese segundo a qual a gênese da consciência responde a uma necessidade interna, imanente ao desenvolvimento dos graus de objetivação da vontade. Trata-se aqui da concepção de base de sua Naturphilosophie: em última instância, é a vontade que responde por todo fenômeno e pela totalidade da natureza, manifestandose como forças naturais primordiais (ursprüngliche Naturkräfte) e como força vital (Lebenskraft). ${ }^{21}$ Há, de acordo com sua filosofia da natureza, uma interação fundamental entre a vontade e o fenômeno, e uma interação tal que todos os fenômenos naturais, se observados corretamente, revelam a preponderância da vontade (mediada pelas ideias) nos efeitos do mundo material. Dentro dessa concepção, todas as causas pertencentes à dimensão do fenômeno (o que engloba desde as causas mecânicas até as excitações e os motivos) não são senão "causas ocasionais" (Schopenhauer 2005, p. 200s.), ${ }^{22}$ isto é, fornecem a ocasião para a manifestação, grau por grau, da vontade una. Esta unidade incondicionada da vontade se expressa, segundo

21 Cf. Mattioli 2013, p. 77.

22 Cf. Malter 1991, p. 260; cf. ainda Brandão 2008, pp. 191-195, onde o autor fala de uma atividade original da matéria (Materie), relacionada a uma força intrínseca de mudança que não necessita de uma causa mecânica externa, pois remete diretamente à vontade.

Cad. Nietzsche, Guarulhos/Porto Seguro, v.39, n.3, p. 77-119, setembro/dezembro, 2018. 
Schopenhauer, na concordância e no "parentesco interior entre todos os seus fenômenos." (Schopenhauer 2005, p. 207)

Nessa filosofia da natureza, o intelecto corresponde ao grau máximo na evolução das manifestações da vontade, é a consumação (Vollendung) $)^{\mathbf{2 3}}$ do seu processo evolutivo. São numerosas as passagens em que Schopenhauer fala do caráter cada vez mais perfeito do intelecto quanto mais ascendemos nas formas orgânicas, até alcançar sua plena perfeição no intelecto humano. ${ }^{24}$ Mas essa noção de perfeição só faz sentido no interior de um campo normativo, o qual, por sua vez, só é possível sob a pressuposição de alguma forma de intencionalidade. Em Kant, esse problema é resolvido pela referência à ideia regulativa de um intellectus archetypus como "fundamento da possibilidade desses fins da natureza" (Kant 2016, p. 401). ${ }^{25}$ Schopenhauer, porém, não apenas recusa qualquer referência (mesmo hipotética) a uma intencionalidade externa ao mundo, numa crítica mordaz à físicoteologia, como toma por ponto de partida de suas reflexões a tese do caráter essencialmente cego e não intencional do princípio metafísico imanente que fundamenta a finalidade da natureza: a vontade una. ${ }^{\mathbf{2 6}}$

23 Cf. Malter 1991, p. 263. Malter argumenta que o lugar atribuído por Schopenhauer ao intelecto no seio da natureza depende da ideia de um processo ou ato direcionado a um fim, que é alcançado justamente no ponto de sua consumação. Essa ideia tornaria profundamente problemática a caracterização da vontade como cega e sem fim. Este é um dos pontos centrais em torno dos quais gira a temática desta parte do trabalho.

24 Cf. sobre isso Mattioli 2018, p. 222ss.

25 É por isso que Kant afirma que "a teleologia não consegue concluir as suas investigações de maneira definitiva a não ser na teologia." (Kant 2016, 399) Não entrarei aqui na discussão se a ideia de um entendimento divino pressuposta na estratégia kantiana de legitimação da consideração teleológica da natureza pode ser identificada à noção de intellectus archetypus (sobre isso, cf. por exemplo McLaughlin 1989, p. 123s.). Para os fins do presente estudo, considerarei que essas noções podem ser tratadas de modo análogo. As referências à Crítica da faculdade de julgar seguem a paginação da Akademie-Ausgabe (AA), volume V (com exceção da Primeira Introdução, que se refere ao volume XX) e a tradução de Fernando Costa Mattos (que contém nas laterais a paginação de AA); as referências à Crítica da razão pura seguem a paginação original padrão das versões A e B.

26 É verdade que, em sua crítica à físico-teologia, Schopenhauer se inspira profundamente nas críticas de Kant e Hume. O problema, porém, é que ele jamais traz explicitamente à discussão aquele outro lado da concepção kantiana da teleologia, que remete à noção de intellectus archetypus (cf. sobre isso Mattioli 2018, p. 212s.) No caso de Nietzsche, apesar de recusar decididamente o recurso à ideia

96 | Cad. Nietzsche, Guarulhos/Porto Seguro, v.39, n.3, p. 77-119, setembro/dezembro, 2018. 
A questão da teleologia nos apontamentos do jovem Nietzsche: Zu...

Apesar disso, sua argumentação geral parece pressupor justamente a existência, na natureza, de uma conformidade a fins inconsciente direcionada ao surgimento do intelecto e da consciência, responsáveis pela origem do mundo como representação. A origem deste último, por sua vez, está associada ao desenvolvimento dos organismos cujas atividades são guiadas por motivos.

Os graus cada vez mais elevados de objetidade da vontade levam finalmente ao ponto no qual o indivíduo, expressando a ideia, não mais pode conseguir seu alimento pelo mero movimento provocado por excitação. [...] Daí ser necessário o movimento por motivo e, por isso, o conhecimento, que portanto aparece como um meio [...] exigido nesse grau de objetivação da vontade [...] A vontade, até então a seguir na obscuridade o seu impulso, com extrema certeza e infalibilidade, acendeu neste grau de sua objetivação uma luz para si, como um meio que se tornou necessário para a supressão da desvantagem que resultaria da profusão e da índole complicada de seus fenômenos, dos mais complexos deles. (Schopenhauer 2005, p. 215)

Como dito acima, essa passagem sugere que devemos entender o processo de objetivação da vontade como um processo marcado por um certo direcionamento e, por conseguinte, por um tipo de intencionalidade. Tudo se passa como se fôssemos solicitados a pressupor uma conformidade a fins na natureza que tornasse possível uma tal ordenação dos fenômenos naturais, que sua interação, apesar de marcada por uma luta constante, resultaria na objetivação plena e última da vontade: o mecanismo representacional. Trata-se de

de uma inteligência divina, não acredito que ele esteja disposto a abandonar a dimensão normativa da vida. Isso fica claro sobretudo em sua obra madura, e acredito que seja possível pensar o seu perfeccionismo justamente sobre o pano de fundo desse complexo de questões. Nesse sentido, a determinação de uma estrutura teleológica na dinâmica das forças vitais me parece um pressuposto necessário para que possamos compreender corretamente aquela dimensão normativa da vida, na medida em que toda forma de vida está ligada a certos interesses vitais. A definição de "interesse" a partir de sua estrutura teleológica é elaborada explicitamente no famoso fragmento sobre o niilismo europeu, no trecho em que Nietzsche pretende desmascarar a moral revelando sua "consideração interessada", isto é, sua "teleologia" (Nachlass/FP 5 [71], KSA 12.211). Essa teleologia pressuposta na moral é justamente aquela que atravessa as "relações de dominação sob as quais se origina o fenômeno “vida"' (JGB/BM § 19, KSA 5.34).

Cad. Nietzsche, Guarulhos/Porto Seguro, v.39, n.3, p. 77-119, setembro/dezembro, 2018. 
Mattioli, W.

uma tese que, na verdade, está pressuposta em toda a teoria das ideias apresentada por Schopenhauer de modo antecipatório já no segundo livro, como pressuposto de sua filosofia da natureza, e mais exaustivamente no terceiro livro do Mundo. As ideias, como objetidade imediata e adequada da vontade, constituem uma dimensão intermediária entre a unidade desta vontade metafísica e a diversidade dos entes naturais, funcionando ao mesmo tempo como modelos universais que se realizam nestes entes. Por outro lado, a ideia é, enquanto representação, um princípio intencional, cognitivo, um objeto para um sujeito (Schopenhauer 2005, p. 242). A conclusão inevitável aqui é que cada ideia é aquilo que determina originariamente o fim (o telos) específico a ser realizado em cada grau ascendente de objetivação da vontade; ela é aquilo que é propriamente visado pela vontade em sua manifestação progressiva na natureza, de modo que o atributo da "perfeição" só poderá ser predicado das formas naturais por sua referência à ideia, isto é, pelo modo como cada forma natural expressa sua ideia. ${ }^{27}$

O parágrafo 28 do primeiro tomo do Mundo é repleto de trechos bastante elucidativos a esse respeito:

Embora no homem, como ideia (platônica), a vontade tenha encontrado sua objetivação mais distinta e perfeita, esta sozinha não podia expressar a sua essência. A ideia de homem, para aparecer na sua atual significação, não podia se expor isolada e separadamente, mas tinha de ser acompanhada por uma sequência decrescente de graus em meio a todas as figuras animais, passando pelo reino vegetal e indo até o inorgânico. Todos esses reinos se complementam para a objetivação plena da vontade. A ideia de homem os pressupõe, assim como as flores das árvores pressupõem folhas, ramos, troncos e raiz. Os reinos da natureza formam uma pirâmide, cujo ápice é o homem. (Schopenhauer 2005, p. 218s.)

27 Cf. Schopenhauer 2005, p. 211: “Conforme o organismo consiga maior ou menor dominação daqueles graus mais básicos das forças da natureza que expressam a objetidade da vontade, tornamse a expressão mais ou menos perfeita de sua ideia, isto é, encontra-se mais ou menos distante do ideal que representa a beleza de sua espécie."

98 | Cad. Nietzsche, Guarulhos/Porto Seguro, v.39, n.3, p. 77-119, setembro/dezembro, 2018. 
A questão da teleologia nos apontamentos do jovem Nietzsche: Zu...

Essa compreensão da natureza como uma "pirâmide" ordenada hierarquicamente será expressa por Schopenhauer através da noção de "finalidade externa", que é marcada por uma "necessidade exterior". Esta se refere ao fato de que cada parte da natureza está conectada às outras conforme a um fim e necessita delas para sua conservação e evolução: o homem necessita dos animais, estes uns dos outros e das plantas, que por sua vez precisam do solo, da água, etc., até o registro dos planetas, do sol, e assim por diante.

Como observa Malter (1991, p. 267), em sua tentativa de incorporar a teleologia à tese da objetivação da vontade, Schopenhauer não explica como é possível o salto, concebido como teleologicamente necessário, da vontade cega (destituída de qualquer mecanismo cognitivo) para a representação. Ele fala da necessidade de tal salto, mas não há qualquer explicação de como ele seria possível, dados os pressupostos de sua metafísica, já discutidos na primeira seção deste trabalho. As afirmações concernentes à necessidade da passagem do estado inconsciente para o estado consciente da vontade são feitas, portanto, de modo inconsequente. Nesse sentido, a questão acerca da origem do intelecto permanece não resolvida.

Quando Nietzsche, nas notas sobre a teleologia, afirma que esta lança uma série de questões importantes que permanecem sem resposta, o exemplo aludido por ele é justamente a questão sobre a origem do intelecto (Nachlass/FP 62 [13], KGW I/4.553). Sabemos que a resposta ensaiada por ele nos apontamentos de Leipzig vai na direção de uma expansão dos limites da representação. Essa resposta nos dá um primeiro indicativo de que, atento em não recair nos paradoxos aos quais Schopenhauer é conduzido pelos pressupostos de sua metafísica, ele deve ao menos pressupor a possibilidade de uma intencionalidade inconsciente agindo nos bastidores dos processos de produção da natureza. Como pretendemos mostrar, porém, essa intencionalidade deve ser essencialmente distinta daquela pressuposta em concepções demasiadamente antropomórficas 
Mattioli, W.

da teleologia. Ela não deve, portanto, ser compreendida como um tipo de racionalidade superior calculadora, que se encontra fora do mundo e que seria responsável por sua arquitetura, tal como ocorre na teleologia teísta. Schopenhauer pode ter servido a Nietzsche, nesse sentido, como um "caminho do meio", já que ele nega qualquer tipo de racionalidade no âmbito da vontade, sentido-se ao mesmo tempo obrigado a reconhecer uma conformidade a fins no desenvolvimento dos seus graus de objetivação. ${ }^{28}$

\section{O "6oder inconsciente" da natureza versus a "razão superior"s}

No início das notas sobre a teleologia, Nietzsche parece mobilizar sua crítica especificamente contra a ideia de uma "razão superior": "contra a teleologia em geral existe a seguinte arma: a demonstração da não-conformidade a fins (Unzweckmäßigen). Com isso é mostrado apenas que a razão superior agiu somente esporadicamente, que há também terreno para razões menores. Portanto, não há um mundo teleológico uno, mas uma inteligência criadora." (Nachhlass/FP 62 [4], KGW I/4.550) ${ }^{29}$ Essa passagem, assim como outros trechos das notas, sugere que Nietzsche limita o escopo de sua crítica à ideia teo-teleológica de uma inteligência divina, racional e onisciente a agir nos bastidores dos processos de produção da natureza. A primeira "prova" contra essa ideia (deduzida da constatação da existência de entes não conformes a fins), parece

28 Tomo a liberdade de remeter o leitor novamente ao artigo em que trato de modo mais detido desse conjunto de problemas em Schopenhauer (Mattioli 2018).

29 A noção de uma "razão superior" parece ser atribuída por Nietzsche tanto às concepções teístas e dogmáticas da teleologia quanto à concepção kantiana, que considera necessária a pressuposição (mesmo que hipotética) de um intelecto divino como único fundamento possível para a finalidade que reconhecemos na natureza: "a ideia de um outro entendimento possível diferente do humano [...] tem de se encontrar aqui como fundamento para que se possa dizer: certos produtos naturais têm de ser considerados por nós como produzidos intencionalmente e como fins segundo a sua possibilidade, tendo em conta a constituição particular do nosso entendimento" (Kant 2016, p. 405); cf. ainda Kant 2015, p. B727; Kant 2016, "Primeira Introdução" (AA XX, p. 181); Kant 2016, p. 400.

100 | Cad. Nietzsche, Guarulhos/Porto Seguro, v.39, n.3, p. 77-119, setembro/dezembro, 2018. 
A questão da teleologia nos apontamentos do jovem Nietzsche: $\mathrm{Zu}$...

preservar ainda a possibilidade da existência do que Nietzsche chama de "razões menores". Ele se vale então do termo "inteligência criadora" para designar o tipo de "intencionalidade não racional" ou de "racionalidade deflacionada" que poderia ainda ser suposta nos processos naturais. Trata-se, assim, de um conceito relativo de conformidade a fins (Nachlass/FP 62 [52], KGW I/4.574), de uma conformidade a fins como resultado de uma tendência criadora inconsciente e imperfeita (Hill 2003, p. 87).

Com efeito, um dos aspectos da crítica de Nietzsche se refere, como aponta Lopes, à "transposição indevida para o âmbito do orgânico" e do reino natural em geral "de nossos critérios de atribuição de racionalidade a escolhas humanas." (Lopes 2008, p. 150) É possível que Nietzsche esteja recusando um determinado tipo demasiadamente otimista e inflacionado de atribuição de racionalidade, sem com isso atacar todo e qualquer tipo de analogia com o humano. Segundo Lopes (2008, p. 150), "Nietzsche concede que as ações humanas são intencionalmente orientadas, mas não que disso possamos concluir que elas sejam necessariamente racionais." O cerne do argumento de Nietzsche encontra-se na seguinte passagem:

$\mathrm{Na}$ vida humana, estabelecemos graus na conformidade a fins: somente identificamos [uma ação] como "racional" quando há um estreito leque de opções. Quando, em uma situação complicada, o homem encontra o único caminho apropriado [zweckmäßig = conforme a fins], dizemos então que ele agiu racionalmente. Se alguém, porém, quiser viajar pelo mundo e se enveredar por um caminho qualquer, estará agindo conforme a fins, mas não racionalmente.

Portanto, nos organismos "conformes a fins" não se revela uma razão. (Nachlass/FP 62 [46], KGW I/4. 569)

Nietzsche está dizendo aqui que só poderíamos atribuir racionalidade ao método de produção da natureza se pudéssemos calcular as possibilidades de escolha dos meios e concluir que a natureza "decidiu" pelo meio mais eficiente tendo em vista o fim a 
Mattioli, W.

ser atingido. Porém, segundo Nietzsche, a vida se apresenta numa infinidade de formas conformes a fins. Não há apenas uma forma possível ou apenas uma forma "ideal" da conformidade a fins para os entes naturais, que poderíamos qualificar como "conformidade a fins superior", mas sim um leque incalculável de possibilidades incomensuráveis. Esse argumento se baseia na tese, cara a Nietzsche desde muito cedo e apresentada como um dos pontos centrais de sua argumentação nessas notas, de que a vida se define por uma multiplicidade infindável e um devir constante. ${ }^{\mathbf{3 0}}$

Ainda no início das notas, logo após mencionar aquela "inteligência criadora", Nietzsche fala da possibilidade de que haja um poder inconsciente criador de conformidade a fins, denominado, de modo um tanto quanto geral, de "natureza" (Nachlass/FP 62 [4], KGW I/4.550). Ele dá então o exemplo do instinto dos animais e sugere que se trata aqui da visão típica da filosofia da natureza (Naturphilosophie). O exemplo do instinto dos animais parece ser retirado da filosofia da natureza de Schopenhauer, a saber, do parágrafo 28 do segundo livro do Mundo que, como vimos, é um dos principais textos do autor dedicados à questão da teleologia. Ali, Schopenhauer sugere que:

o instinto dos animais nos fornece o melhor esclarecimento para a restante teleologia da natureza. Pois, se o instinto é como se fosse um agir conforme um conceito de fim, no entanto completamente destituído dele, assim também todos os quadros da natureza se assemelham aos feitos conforme a um conceito de fim e no entanto completamente destituídos dele. (Schopenhauer 2015, p. 227)

É possível que Nietzsche tenha encontrado aqui uma alternativa à concepção otimista e inflacionada da teleologia teísta num conceito um tanto quanto inespecífico de "inconsciente" como uma força natural criadora de formas. De acordo com Claudia Crawford (1988, p. 109s.), Nietzsche estaria estabelecendo uma dicotomia entre, por

30 Falaremos um pouco mais sobre isso na segunda parte deste estudo.

102 | Cad. Nietzsche, Guarulhos/Porto Seguro, v.39, n.3, p. 77-119, setembro/dezembro, 2018. 
A questão da teleologia nos apontamentos do jovem Nietzsche: Zu...

um lado, a consciência inteligente dotada de conceitos presente no tipo de racionalidade que imputamos a nós mesmos e, por outro, uma força inconsciente agindo na natureza.

Ora, se temos em mente a discussão da primeira seção em torno dos apontamentos de Leipzig, a tese de que Nietzsche se inspira em certa medida em Schopenhauer na tentativa de encontrar uma noção não intelectualista e deflacionada de intencionalidade, que deveria ser pressuposta nos processos de produção da natureza, pode parecer bastante paradoxal. A constatação à qual fomos conduzidos ali era justamente a de que Nietzsche recusava a atribuição por parte de Schopenhauer de um caráter absolutamente não-intencional à dimensão da vontade, resultante de seu dualismo metafísico básico entre vontade e representação. Se essa tese está correta, Nietzsche não poderia ter encontrado em Schopenhauer um conceito de intencionalidade capaz responder pelos processos de produção da natureza enquanto tal. Como vimos na seção anterior, porém, esse aparente paradoxo é, mais uma vez, fruto das ambiguidades da metafísica da vontade e de seu momento teleológico; ambiguidades das quais Nietzsche soube se valer de modo produtivo na sua própria concepção de como devemos entender a teleologia.

Ademais, apesar de se inspirar em certa medida em Schopenhauer na tentativa de encontrar uma noção não intelectualista de intencionalidade, Nietzsche mobiliza seus argumentos também contra a concepção de teleologia deste último, sobretudo na medida em que ela se baseia na noção de unidade da vontade. Com efeito, um dos argumentos centrais de Schopenhauer, apresentado ainda no parágrafo 28 do segundo livro, sugere que o único verdadeiro esclarecimento acerca da harmonia interna dos fenômenos naturais, de sua acomodação recíproca e da necessidade de sua gradação nos é dado mediante o conhecimento da unidade da vontade (Schopenhauer 2015, p. 219s.). Nietzsche se refere a este argumento ao escrever em suas notas: "A coisa em si deve mostrar sua unidade na harmonia 
Mattioli, W.

de todos os fenômenos. Todas as partes da natureza se encaixam, pois se trata de uma vontade una." (Nachlass/FP 62 [7], KGW $\mathrm{I} / 4.551)^{31}$ A concepção segundo a qual todas as partes da natureza são interdependentes e têm um papel funcional na organização e no desenvolvimento do todo é complementada por Schopenhauer pela constatação de que, "no fundo, tudo isso se assenta no fato de a vontade ter de devorar a si mesma, já que nada existe exterior a ela, e ela é uma vontade faminta. Daí a caça, a angústia, o sofrimento." (Schopenhauer 2005, p. 219) Ou seja, a interdependência das partes da natureza implica que elas necessitam umas das outras como alimento, o que resulta na luta ininterrupta da matéria pela matéria. No caso de Schopenhauer, portanto, não há uma associação, pelo menos do ponto de vista do próprio autor, entre teleologia e otimismo, como é sugerido por Nietzsche no início de suas notas (Nachlass/FP 62 [4], KGW I/4.549). Poder-se-ia objetar aqui, entretanto, que há também aqui uma inconsistência na formulação schopenhaueriana do problema, assim como se pode notar uma certa inconsistência ou pelo menos uma ambiguidade fundamental na elaboração de sua teleologia, dada sua tese do caráter cego da vontade. E é isso, na verdade, que sugere o texto do próprio Nietzsche, uma vez que, para este, a constatação de uma luta terrível entre os indivíduos e as espécies é um argumento contra a teleologia: "a antítese de toda a teoria se configura por aquela luta terrível dos indivíduos (que também manifestam uma ideia) e das espécies" (Nachlass/FP 62 [7], KGW I/4.551). A desarmonia das partes da natureza, constatável na luta sem fim que se trava entre elas, seria, assim, prova da existência da "não-conformidade a fins" (Unzweckmäßigen), o que, como vimos, já seria uma objeção contra a tese de um "mundo teleológico uno", tal como pressuposto por Schopenhauer, apesar de não refutar a hipótese

31 A passagem de onde Nietzsche retira este trecho se encontra em Schopenhauer 2005, p. 226: "devemos não apenas assumir que cada espécie se adapta às circunstâncias encontradas previamente, mas também estas, precedendo as espécies no tempo, levam igualmente em conta os seres que ainda estão por vir. Pois se trata de uma única vontade que se objetiva no mundo."

104 | Cad. Nietzsche, Guarulhos/Porto Seguro, v.39, n.3, p. 77-119, setembro/dezembro, 2018. 
A questão da teleologia nos apontamentos do jovem Nietzsche: $\mathrm{Zu}$...

menos onerosa de mecanismos intencionais "inferiores" em ação nos processos naturais (Nachlass/FP 62 [4], KGW I/4.550). Para Nietzsche, "a explicação [oferecida por Schopenhauer] pressupõe, portanto, uma teleologia invariável (eine durchgehende Teleologie) que não existe." (Nachlass/FP 62 [7], KGW I/4.551)

$\mathrm{O}$ fato é que Schopenhauer concede à tese da unidade da vontade o mesmo papel explicativo que possuía a suposição de uma inteligência divina na teleologia teísta. ${ }^{32}$ Suas conclusões são praticamente as mesmas:

a translação dos planetas, a obliquidade da elíptica, a rotação da terra, a separação entre terra firme e oceanos, a atmosfera, a luz, o calor e todos os fenômenos semelhantes, que na natureza são aquilo que o baixo fundamental é na harmonia, acomodam-se plenos de pressentimento à geração futura de seres vivos, dos quais serão o sustentáculo mantenedor. Do mesmo modo, o solo se adapta à alimentação dos predadores, e todos estes àquele primeiro. Todas as partes da natureza se encaixam, pois é uma vontade una que aparece em todas elas (Schopenhauer 2005, p. 226).

Nietzsche rejeita essa concepção, mas parece manter aquilo que lhe é sugerido por suas ambiguidades: a possibilidade de se pensar uma conformidade a fins associada a um certo tipo de intencionalidade inconsciente que nada tem a ver com a razão divina pressuposta hipoteticamente no kantismo e dogmaticamente na teleologia teísta. Como ele nos diz: "deve-se afastar todo interesse teológico da questão." (Nachlass/FP 62 [5], KGW I/4.550) Seria então o objetivo principal de Nietzsche nesse momento rejeitar uma concepção teológica parasitária da visão teleológica? É isso

32 Cf. Hill 2003, p. 80. Essa afirmação pode e deve ser obviamente contrabalançada pela crítica explícita de Schopenhauer à físico-teologia, presente em todos os momentos relevantes de sua obra nos quais ele trata do tema da teleologia. Isso porém, em nada atinge o ponto principal da afirmação; pelo contrário, apenas o corrobora, já que, ao recusar a prova físico-teológica, Schopenhauer precisa fornecer um princípio explicativo alternativo capaz de dar conta, igualmente, da "absoluta conformidade a fins" e da "evidente intencionalidade em todas as partes do organismo animal" (p. 86). Esse princípio alternativo, a unidade da vontade, assume assim o mesmo papel que a figura de Deus (inteligência divina) ocupava na teleologia teísta.

Cad. Nietzsche, Guarulhos/Porto Seguro, v.39, n.3, p. 77-119, setembro/dezembro, 2018. 
Mattioli, W.

que nos é sugerido também pela seguinte passagem: “A eliminação da teleologia tem um valor prático: trata-se somente de recusar o conceito de uma razão superior: com isso já estaremos satisfeitos" (Nachlass/FP 62 [16], KGW I/4.554).

Não podemos deixar de notar, contudo, que muitas das passagens desses apontamentos são ambíguas e podem ser lidas na contramão da tese que procuramos defender. A interpretação dessas notas depende fundamentalmente da forma como entendemos o uso que faz Nietzsche das noções de razão, racionalidade, inteligência e inconsciente. Dado o caráter experimental, fragmentário e nada sistemático desses apontamentos, esse uso é profundamente equívoco. No início das notas havíamos encontrado ocasião para sugerir que Nietzsche estaria buscando entender a conformidade a fins a partir de algumas noções um tanto quanto inespecíficas como "razões menores", "inteligência criadora" e "poder inconsciente criador". A seguinte passagem, porém, parece refutar essa hipótese: "A vida, o organismo, não atesta uma inteligência superior: não atesta absolutamente nenhum grau invariável de inteligência. A existência dos organismos mostra apenas forças atuando cegamente." (Nachlass/FP 62 [36], KGW I/4.563)

Uma maneira de sustentar a credibilidade de minha hipótese frente às ambiguidades em questão e, em especial, frente à sua aparente refutação nesta passagem, é ressaltar o adjetivo usado por Nietzsche para qualificar o termo "inteligência", tal como empregado por ele aqui. Nietzsche diz que não há nenhum "grau invariável de inteligência" (keinen durchgehenden Grad von Intellegenz). O adjetivo é o mesmo utilizado por ele ao rejeitar a concepção schopenhaueriana de teleologia: "uma teleologia invariável (eine durchgehende Teleologie), que não existe." (Nachlass/FP 62 [7], KGW I/4.551) Tal adjetivo (durchgehend) cobre qualidades como constância, invariabilidade, uniformidade (unidade) e universalidade. Nesse sentido, podemos pensar que a posição de Nietzsche consiste em afirmar que o processo de produção natural não é guiado por um método conforme a fins capaz de produzir

106 | Cad. Nietzsche, Guarulhos/Porto Seguro, v.39, n.3, p. 77-119, setembro/dezembro, 2018. 
A questão da teleologia nos apontamentos do jovem Nietzsche: Zu...

uma atividade constante, contínua, homogênea, como resultado de um tipo de unidade metafísica fundamental exemplificada tanto pela ideia de uma entidade divina quanto pela noção schopenhaueriana de uma vontade una. Ao contrário, devemos pensar a noção de conformidade a fins a partir da ideia de uma multiplicidade de componentes teleológicos "menores" ("geringere Vernünfte", Nachlass/FP 62 [4], KGW I/4.550), ${ }^{33}$ cuja interação não constitui um todo harmônico e perfeito capaz de satisfazer nosso ideal racional de totalidade e unidade, mas sim uma natureza apenas parcialmente harmônica - uma conformidade a fins relativa (Nachlass/FP 62 [52], KGW I/4.574) -, da qual o conflito e a imperfeição são partes constituintes. Assim, estaremos ainda autorizados a falar em um tipo de "inteligência" (ou "inteligências", como, aliás, o faz o próprio Nietzsche), sem com isso recairmos no escopo de sua crítica.

Mas essa solução dá conta apenas do problema apresentado na primeira parte do trecho acima citado, onde é dito que o organismo não prova nenhum grau invariável de inteligência. Há ainda a segunda parte: "A existência dos organismos mostra apenas forças atuando cegamente." (Nachlass/FP 62 [36], KGW I/4.563) Esta é a tese mecanicista vinculada por Nietzsche, via Lange, à teoria darwinista. Ela diz respeito à noção de acaso e configura um dos momentos centrais de sua crítica à teleologia, sobre o qual nos debruçaremos agora.

\section{Darwin e Empédocles: mecanismo, acasos favoráveis e a vida como limite}

Quando, no início das notas, Nietzsche sugere a existência de "razões menores", de uma "inteligência criadora" ou de um "poder inconsciente criador" como um tipo de mecanismo imanente ao mundo, ele termina dizendo que ainda assim permanecemos no âmbito da metafísica. A remissão deste poder inconsciente criador a

33 Cf. sobre isso Miller 2006, p. 65s.

Cad. Nietzsche, Guarulhos/Porto Seguro, v.39, n.3, p. 77-119, setembro/dezembro, 2018. 
uma concepção metafísica se dá em função da identificação operada por ele aqui entre a filosofia da natureza e a metafísica da vontade de Schopenhauer. Ele afirma então: “por fim, pode ser possível uma solução a partir de um ponto de vista rigorosamente humano: a solução empedocliana, na qual a conformidade a fins aparece apenas como um caso entre muitos não conformes a fins." (Nachlass/FP 62 [4], KGW I/4.550) O que está por trás dessa afirmação é a tese de que podemos explicar o surgimento da conformidade a fins no reino natural com base em princípios puramente mecânicos. Segundo o jovem filólogo, a necessidade postulada por Kant de que pensemos os organismos e os produtos da natureza em geral como premeditados, segundo um plano racional, não existe mais. Inspirado pela discussão de Lange acerca do darwinismo, ele parece negar, nesse momento, que sejamos obrigados a lançar mão de juízos de finalidade no âmbito das ciências da natureza, uma vez que o surgimento dos organismos poderia agora ser explicado pela combinação da causalidade mecânica com a hipótese de acasos favoráveis. ${ }^{34}$ A referência a Empédocles é testemunho da influência direta da leitura de Lange. ${ }^{35}$ Atento às consequências que a teoria darwinista da luta pela existência traz para a tese teleológica, Lange a associa à refutação de Empédocles das teorias teleológicas a partir de sua doutrina dos acasos favoráveis. Isso dissolveria a necessidade de se pensar o conceito de conformidade a fins mediante a noção de causa final e, com isso, a necessidade de se pensar a natureza como um sistema de fins ao qual poderíamos atribuir uma teleologia externa. $\mathrm{O}$ argumento central de Lange diz respeito ao esbanjamento da natureza na criação dos seus produtos:

34 Cf. Lopes 2008, p. 148.

35 A associação entre Darwin e Empédocles é feita por Lange inicialmente por ocasião da discussão de uma resenha do livro de Christian Radenhausen, Isis: der Mensch und die Welt, no qual o autor faz remontar as consequências da teoria de Darwin à oposição de Empédocles contra a teleologia (Lange 1866, p. 401s.) Nietzsche parece ter adquirido o livro de Radenhausen no início de 1868, provavelmente motivado pela discussão de Lange (cf. Brobjer 2007, p. 241).

108 | Cad. Nietzsche, Guarulhos/Porto Seguro, v.39, n.3, p. 77-119, setembro/dezembro, 2018. 
A questão da teleologia nos apontamentos do jovem Nietzsche: Zu...

Se um homem, para atirar em um coelho, disparasse milhões de projéteis em campo aberto para todas as direções possíveis; se, para entrar num quarto trancado, ele comprasse dez mil chaves aleatórias e experimentasse todas elas; se, para ter uma casa, ele construísse uma cidade e deixasse as casas restantes ao vento e à ação do tempo, ninguém denominaria algo assim conforme a fins e muito menos suporíamos, por detrás desse procedimento, uma sabedoria mais elevada, uma razão oculta e uma inteligência superior. (Lange 1866, p. 403)

Lange argumenta que esse é exatamente o modo segundo o qual procede a natureza. As leis da conservação e da reprodução das espécies, cujo conhecimento nos é dado pelas mais recentes ciências naturais, demonstram que há um desperdício colossal de embriões em todos os processos de reprodução na natureza. A perpetuação da espécie exige o perecimento de um número incalculável de seres para que haja ocasionalmente o encontro das condições adequadas que tornarão possíveis a manutenção e o desenvolvimento da vida. Portanto, o perecimento de embriões e o fracasso de uma infinidade de processos vitais já iniciados constituem a regra: o desenvolvimento apropriado (zweckmäßig) e "natural" é a exceção, determinada pela conjunção de acasos favoráveis. Nesse sentido, o "método da natureza" é radicalmente diferente daquilo que identificamos como o método racional próprio à inteligência calculadora humana.

Numa das notas escritas a partir da leitura dessas passagens de Lange, Nietzsche diz: "Por outro lado, conhecemos o método da natureza de como um tal corpo 'conforme a fins' se origina, um método absurdo (sinnlose)." (Nachlass/FP 62 [12], KGW I/4.553) ${ }^{36}$ Em outra passagem, na qual ele cita Schopenhauer, lemos o seguinte: "à natureza as obras não custam nenhum esforço; por isso a destruição é indiferente" (Nachlass/FP 62 [29], KGW I/4.561). Note-se que Nietzsche recorre também a Schopenhauer na tentativa de creditar a

36 Para uma discussão aprofundada deste tópico, cf. Toscano 2001. Apesar de Toscano elaborar uma leitura bastante sofisticada dessas notas, discordo de seu argumento central, que deduz da posição assumida por Nietzsche uma rejeição completa da teleologia e da noção de intencionalidade.

Cad. Nietzsche, Guarulhos/Porto Seguro, v.39, n.3, p. 77-119, setembro/dezembro, 2018. 
Mattioli, W.

tese segundo a qual o método da natureza se define fundamentalmente por um esbanjamento irracional dos meios. Mas, como sabemos, as conclusões de Schopenhauer e de Lange são diferentes.

Schopenhauer reconhece que a natureza procede prodigamente, mas isso não constitui para ele um argumento contra a teleologia. No trecho do qual Nietzsche retira a citação acima, Schopenhauer reconduz o sentimento de espanto com o qual constatamos a prodigalidade da natureza a uma anfibolia dos conceitos. É verdade que nos espantamos ao verificar que a natureza destrói constantemente milhões dos seus produtos, cuja complexidade estrutural nos causa imensa admiração, mas esse espanto desaparece tão logo percebemos que ele se baseia num cálculo comparativo inválido: diferentemente do que ocorre com as produções humanas, que dependem da mediação do intelecto racional e do labor sobre uma matéria estranha, o que exige um enorme esforço, as produções da natureza não lhe custam esforço algum (Schopenhauer 2015, p. 397). Nesse sentido, afirmar que a natureza não procede conforme a fins pois seu método de produção não corresponde à racionalidade empregada nas produções humanas seria um mau uso (por excesso) do argumento da analogia técnica. Com efeito, não estamos autorizados a esperar que a natureza aja em conformidade com o método racional próprio às atividades humanas, simplesmente porque que não estamos autorizados a imputar racionalidade à natureza. $\mathrm{O}$ tipo de conformidade a fins que encontramos aqui deve ser de outra ordem. ${ }^{37}$ Assim como a luta constante da qual a vida é palco não é, para Schopenhauer, um argumento contra a teleologia, tampouco o é o fato de que a natureza abandona à destruição a maior parte de suas criações. A familiaridade de Nietzsche com esse argumento pode ter servido como um contrapeso com relação à forma como ele parece ter se apropriado dos argumentos de Lange em favor do darwinismo e contra a teleologia.

37 Cf. sobre isso De Cian 2008.

$110 \mid$ Cad. Nietzsche, Guarulhos/Porto Seguro, v.39, n.3, p. 77-119, setembro/dezembro, 2018. 
A questão da teleologia nos apontamentos do jovem Nietzsche: Zu...

Mas Lange, por outro lado, acusa os materialistas dogmáticos de serem incapazes de perceber que as concepções teleológicas, enquanto rebentos genuinamente espontâneos do espírito humano, fazem parte do patrimônio mais nobre do homem e tornam possível uma certa disposição de espírito e uma felicidade que não poderiam ser alcançadas por outros meios. ${ }^{38}$ Seria possível que parte da indecisão de Nietzsche quanto à aceitação de certas noções teleológicas tenha como pano de fundo sua adesão ao "ponto de vista do ideal", tal como defendido por Lange? ${ }^{39}$ É possível que sim. Essa leitura faz jus tanto às críticas de Nietzsche à visão teleológica quanto à sua aparente tentativa de salvaguardar um tipo menos oneroso de teleologia. Se essa tese estiver correta, então Nietzsche está dizendo que devemos prezar a teleologia como fabulação conceitual para fins edificantes, ao passo que, no âmbito epistemológico, devemos nos ater às explicações mecanicistas da natureza, isto é, ao darwinismo e ao empedoclismo. $\mathrm{O}$ surgimento de organismos conformes a fins deveria ser entendido como um evento possível entre um número incalculável de eventos possíveis num mundo determinado por leis puramente mecânicas. Isso é o que parece atestar a seguinte passagem: "a conformidade a fins originada como um caso especial do possível: um sem número de formas se originam, isto é, combinações mecânicas: entre essas inúmeras [formas] pode haver também formas capazes de vida."

38 Cf. Lange 1866, p. 200: "Os materialistas, ao defenderem a regularidade de todo evento, persistem nesse círculo de ideias de modo muito leviano e com uma unilateralidade que é danosa para a correta estima (Würdigung) da vida espiritual, na medida em que apenas concepções humanas desempenham um papel nesse âmbito. Tão logo as concepções da teleologia, da inteligência na natureza, da ordenação e da alteração, etc. são destituídas da suposta objetividade, muito rapidamente surge o efeito de que essas concepç̃̃es são consideradas como inferiores em seu valor para o homem, quando não são simplesmente descartadas como algo destituído de qualquer valor." Em pelo menos um momento das notas, Nietzsche parece compartilhar essa posição: "a teleologia é, assim como o otimismo, um produto estético." (Nachl ass/FP 62 [17], KGW I/4.554) Imediatamente antes desse trecho, lemos: "Valorização da teleologia em sua estima (Wiirdigung) pelo mundo humano das ideias." (Nachlass/ FP 62 [17], KGW I/4.554)

39 Sobre a adesão de Nietzsche àquilo que Lange chama de "ponto de vista do ideal", e que corresponde à perspectiva do idealismo prático, cf. Lopes 2008, pp. 75-95.

Cad. Nietzsche, Guarulhos/Porto Seguro, v.39, n.3, p. 77-119, setembro/dezembro, 2018. 
(Nachlass/FP 62 [27], KGW I/4.559) Este trecho é também retirado de Lange (1866, p. 404s.). ${ }^{40}$

Por outro lado, Claudia Crawford (1988, p. 120) parece estar certa quando argumenta que Nietzsche não sustenta uma compreensão puramente mecanicista de forças absolutamente cegas atuando na natureza. Antes, ele estaria buscando uma conciliação entre

40 Cf. ainda Nachlass/FP 63[12], KGW I/4.553 e Nachlass/FP 62[45], KGW I/4.568. Essas passagens corroboram uma interpretação que atribui um caráter meramente estratégico à possível adesão de Nietzsche a uma visão de mundo compatível com algum tipo de teleologia. Como produto estético, uma concepção da natureza capaz de incorporar a noção de intencionalidade responderia a interesses práticos, sem ter qualquer relação com nossos interesses genuinamente cognitivos, cuja satisfação estaria restrita ao âmbito da investigação científica, identificada aqui ao materialismo mecanicista. Há razões para crermos que essa é de fato a atitude assumida por Nietzsche. Duas cartas desse período, uma a von Gersdorff (agosto de 1866) e outra a Paul Deussen (abril/maio de 1868) dão testemunho do compromisso de Nietzsche com o ceticismo epistemológico e o materialismo metódico, por um lado, e com a visão da metafísica como fiç̧ão conceitual, por outro (cf. Lopes 2008, p. 85ss.). Contudo, essa interpretação se depara com alguns problemas. Em primeiro lugar, como pretendemos mostrar, Nietzsche não parece conceder a última palavra ao mecanicismo no que tange à explicação do fenômeno da vida. Em segundo lugar, tal interpretação parece conceder um peso muito grande ao engajamento de Nietzsche com o programa de Lange e à distinção estabelecida por este entre o que deve ser entendido como ciência, seu objeto e seus limites, por um lado, e o que deve ser visado puramente do ponto de vista do ideal, por outro. Com isso, ela não consegue dar uma resposta satisfatória à questão da adesão de Nietzsche a uma concepção da teleologia como algo interno aos próprios princípios da ciência da natureza, que encontramos em seus apontamentos do ano seguinte. Falaremos sobre esse ponto na segunda parte deste estudo, onde indicaremos a importância da influência de Eduard von Hartmann sobre o jovem Nietzsche. Vale adiantar aqui, porém, que a postura assumida então por Nietzsche frente à teleologia não parece se reduzir a um interesse meramente estratégico e de natureza prática, que dependeria do ponto de vista do ideal, mas responde a um interesse legitimamente cognitivo no âmbito da própria investigação científica. Assim, se é verdade, por um lado, que ele considera o reino da metafísica, enquanto reino da "verdade absoluta", da essência ou da realidade em si, como uma dimensão que ultrapassa o alcance de nossos empreendimentos científicos (como fica claro em suas cartas a Deussen e von Gersdorff), por outro lado, a assunção de algum tipo de teleologia na natureza, uma vez que a tenhamos destituído de sua suposta fundamentação teológica, não traz consigo a pretensão de um conhecimento da verdade absoluta ou do em-si extrafenomênico do mundo. Com uma teleologia naturalizada estaríamos ainda no registro do fenômeno (cf. sobre isso Schlüpmann 1977, p. 28). Nesse sentido, é possível que Nietzsche esteja propondo que a ciência poderia e deveria expandir seus horizontes para além da mera causalidade mecânica, sem que com isso seu status científico esteja ameaçado. Isso o distanciaria parcialmente da compreensão de Lange do método e dos limites da ciência da natureza, o que não significa introduzi-la necessariamente no registro da pura especulação metafísica. Ele certamente não pretende que a ciência da vida seja relegada à teologia ou à metafísica. Mas ao mesmo tempo ele não acredita que a vida possa ser explicada pelos modelos mecanicistas. Deve haver então uma solução intermediária: nem teocracia, nem fisiocracia. É nesse espaço intermediário que a posição assumida pelo jovem Nietzsche parece adquirir seu significado próprio.

112 | Cad. Nietzsche, Guarulhos/Porto Seguro, v.39, n.3, p. 77-119, setembro/dezembro, 2018. 
A questão da teleologia nos apontamentos do jovem Nietzsche: Zu...

mecanismo estrito e teleologia através de quatro argumentos ou quatro "pontos" mencionados no fragmento 62 [37]. Os quatro pontos são os seguintes: "1. Eliminação da concepção expandida de teleologia. / 2. Limites do conceito. A conformidade a fins na natureza. / 3. Conforme a fins igual a capaz de existência. / 4. Organismos como pluralidades e unidades." (Nachlass/FP 62 [37], KGW I/4.563)

Infelizmente, Crawford não deixa claro em que sentido esses quatro pontos refutariam a tese de que há somente forças cegas agindo na natureza. Uma possibilidade de interpretação é pensar que o primeiro ponto diz respeito à eliminação apenas da teleologia antropomórfica e teísta, deixando aberta a possibilidade de se pensar formas minimalistas de intencionalidade. Nesse sentido, o segundo ponto se referiria à limitação do conceito de conformidade a fins à conformidade a fins interna. Isso conduziria então ao terceiro ponto: entender a conformidade a fins como capacidade de viver (se a conformidade a fins do organismo não pode ser remetida a uma causa final que lhe é externa, o que nos resta desse conceito é sua referência à capacidade de autorregulação e autoconservação do organismo, isto é, sua capacidade de viver), e entender a vida como o segredo que, em última instância, não pode ser explicado nem pela tese mecanicista, nem pela versão kantiana da teleologia. Por fim, o quarto ponto diz respeito à tese de que nosso conceito de unidade, a partir do qual entendemos o organismo como indivíduo organizado, é relativo: toda unidade, seja ela orgânica ou inorgânica, envolve uma multiplicidade. Este ponto está associado à tentativa de Nietzsche de suprimir os limites entre mecanismo e teleologia, como veremos na segunda parte deste estudo.

A seção na qual se encontram esses quatro argumentos é intitulada "Uma falsa antinomia". As notas que se seguem ao título parecem indicar, como argumenta Crawford, que Nietzsche entende a posição estritamente mecanicista como uma falsa antinomia à posição kantiana. Essa interpretação é plausível se temos em mente, 
Mattioli, W.

antecipando a discussão que faremos posteriormente, que ele pretende dissolver a antinomia entre mecanismo e teleologia. O que está por trás deste argumento parece ser a compreensão de que o fenômeno da vida, como resultado de um arranjo complexo de forças naturais, não pode ser explicado integralmente através de uma redução estrita ao mecanicismo. A vida, para Nietzsche, permanece um segredo: "denominamos conforme a fins aquilo que se mostra capaz de vida. O segredo é somente 'a vida" (Nachlass/FP 62 [29], KGW I/4.561).

Nietzsche aceita que, no que diz respeito à sua forma, uma descrição mecânica acerca da origem do organismo seja possível: "Portanto, quando os cientistas naturais afirmam que um organismo pode se originar a partir do acaso, isto é, não segundo causas finais, pode-se admiti-lo no que diz respeito à forma. A questão que se coloca, porém, é: o que é a “vida'." (Nachlass/FP 62 [47], KGW I/4.572) O que essa passagem deixa entrever é que, aos olhos de Nietzsche, a questão da vida enquanto tal não pode ser respondida pelo materialismo e o mecanicismo. Ela exige um outro tipo de abordagem.

Notemos então que, em sua apropriação dos argumentos em favor do darwinismo, Nietzsche concede que a forma do organismo pode agora ser explicada mecanicamente. $O$ problema aqui, porém, é que o organismo, para ele, não é apenas forma. Um organismo é uma forma determinada entre muitas formas possíveis que abrigam uma manifestação específica da vida ou "força vital"; ou seja, em suas palavras, o organismo é "vida formada (geformtes Leben)" (Nachlass/ FP 62 [46], KGW I/4.569), ele é vida mais forma. No fragmento 62 [25], lemos: "o organismo é uma forma. Se abstrairmos da forma, ele é uma pluralidade" (Nachlass/FP 62 [25], KGW I/4.558); mais à frente: "todas as formas podem ser descartadas, mas a vida!" (Nachlass/FP 62 [46], KGW I/4.570) Nesses trechos, a vida é pensada em termos de uma multiplicidade vital e produtiva em constante devir: "O que nós retemos de um ser vivo não é nada mais do que formas. O que vem a ser eternamente é a vida" (Nachlass/FP 62 [46], KGW I/4.570).

114 | Cad. Nietzsche, Guarulhos/Porto Seguro, v.39, n.3, p. 77-119, setembro/dezembro, 2018. 
A questão da teleologia nos apontamentos do jovem Nietzsche: Zu...

Se retomarmos agora uma das passagens mais importantes de Lange, que serve como ponto de partida para o fragmento 62 [25] citado acima, veremos que o organismo é definido ali como forma mais matéria (Stoff): "se atentarmos à forma de uma coisa, esta é uma unidade; se abstrairmos da forma, ela é uma pluralidade ou matéria (Stoff)" (Lange 1866, p. 407). Apesar de falar aqui em "coisa", e não exatamente em "organismo", o contexto do qual a citação é retirada deixa claro que se trata de uma discussão em torno do indivíduo orgânico. Do ponto de vista da explicação mecânica e darwinista, esta definição do organismo como forma mais matéria cumpre exemplarmente bem o papel que lhe cabe: ser a base para uma concepção reducionista, que explica o surgimento da forma mediante a ideia de uma sequência de acasos favoráveis na série da causalidade mecânica (material). Contudo, em sua tentativa de compreender a constituição do organismo, Nietzsche parece substituir a noção de "matéria", presente no trecho de Lange, pela noção de "vida". Notemos que no fragmento 62[25], retirado diretamente de Lange, Nietzsche caracteriza o organismo, uma vez que se abstraia de sua forma, como uma pluralidade; mas ele exclui o termo complementar presente em Lange: a matéria (Stoff). Ora, este é justamente o termo que, no interior da explicação mecanicista, determina a natureza daquela pluralidade. Como vimos nas outras passagens citadas acima, Nietzsche determina então essa pluralidade não em termos de "matéria", mas sim em termos de "vida", de modo que a fórmula: organismo $=$ forma + matéria se torna em Nietzsche: organismo $=$ forma + vida; ou: organismo é "vida formada" (Nachlass/FP 62 [46], KGW I/4.569).

A vida, entendida como multiplicidade produtiva em constante devir, será vista então como o elemento fundamental daquela dimensão que antecede a modalidade de individuação fundada nas operações do intelecto e, enquanto tal, escapa à explicação mecânica. É isso que, ao meu ver, está por trás da noção de "força vital (Lebenskraft)" 
Mattioli, W.

apresentada por Nietzsche, em um de seus esboços do que seria o plano de sua tese, como um tópico a ser desenvolvido num capítulo específico (Nachlass/FP 62 [49], KGW I/4.573). Mas este é um tema que discutirei em mais detalhes na segunda parte deste estudo.

\begin{abstract}
This paper corresponds to the first of two parts that make up a study on the question of teleology in the notes of the young Nietzsche between 1867 and 1869. On the whole, the study intends to offer a reading of three sets of notes written by the philosopher in that period: Zu Schopenhauer, Zur Teleologie, and Vom Ursprung der Sprache, with a clear focus on the notes on teleology of 1868. My aim is to try to show that, despite Nietzsche's various criticisms of teleology and his apparent adherence (via Lange) to Darwinism, his position is best understood as a kind of vitalism, which is receptive to the idea of an unconscious intentionality in nature, but which explicitly rejects the anthropomorphically inflated conception of a divine designer. In this first part of the study, I focus on an analysis of the text $Z u$ Schopenhauer and part of the set of notes collected under the title Zur Teleologie.

Key-Words: Nietzsche, teleology, intentionality, nature, unconscious.
\end{abstract}

\title{
Referências bibliográficas
}

BARBERA, S. Eine Quelle der frühen Schopenhauer-Kritik Nietzsches. Rudolf Hayms Aufsatz „Arthur Schopenhauer“. In: Nietzsche-Studien, n. 24, p. 124$136,1995$.

BRANDÃO, E. A concepção de matéria na obra de Schopenhauer. São Paulo: Humanitas, 2008.

BROBJER, T. Nietzsche and the English: The Influence of British and American Thinking on His Philosophy. New York: Humanity Books, 2007.

CACCIOLA, M. A questão do finalismo na filosofia de Schopenhauer. In: Discurso, n. 20, p. 79-98, 1993.

Schopenhauer e a questão do dogmatismo. São Paulo: Editora da Universidade de São Paulo, 1994.

116 | Cad. Nietzsche, Guarulhos/Porto Seguro, v.39, n.3, p. 77-119, setembro/dezembro, 2018. 
A questão da teleologia nos apontamentos do jovem Nietzsche: Zu...

CRAWFORD, C. The Beginnings of Nietzsche's Theory of Language. Berlin. New York: Walter de Gruyter, 1988.

CRUZ, M. Nietzsche and the Nineteenth-Century Debate on Teleology. In: LEMM, V. (ed.) Nietzsche and the Becoming of Life. New York: Fordham University Press, 2014, p. 67-81.

DALLA VECCHIA, R. Nietzsche e o proto-perspectivismo de Zur Teleologie. In: Philósophos, v. 21, n. 2, p. 219-251, 2016.

DE CIAN, N. Unintelligent Purposes. Schopenhauer's Way over Kantian Teleology. In: MICHELINI, F.; ILLETTERATI, L. (ed.) Purposiveness. Teleology Between Nature and Mind. Frankfurt / Paris / Lancaster / New Brunswick: Ontos Verlag, 2008, p. 97-111.

DENNETT, D. Kinds of Minds. Toward an Understanding of Consciousness. New York: BasicBooks, 1996.

EMDEN, C. Nietzsche's Naturalism. Philosophy and the Life Sciences in the Nineteenth Century. Cambridge: Cambridge University Press, 2014.

GENTILI, C. Kants „kindischer“ Anthropomorphismus. Nietzsches Kritik der „objektiven“ Teleologie. In: Nietzsche-Studien, n. 39, p. 100-119, 2010.

GOY, I; WATKINS, E. (ed.) Kant's Theory of Biology. Berlin / Boston: Walter de Gruyter, 2014.

HILL, K. Nietzsche's Critiques. The Kantian Foundations of his Thought. Oxford: Oxford University Press, 2003.

HIMMELMANN, B. On Teleological Judgement: A Debate between Kant and Nietzsche. In: BRUSOTTI, M.; SIMENS, H. (ed.) Nietzsche, Kant and the Problem of Metaphysics. London / New York: Bloomsbury, 2017, p. 167-179.

ILLETTERATI, L.; MICHELINI, F. (ed.) Purposiveness. Teleology Between Nature and Mind. Frankfurt / Paris / Lancaster / New Brunswick: Ontos Verlag, 2008.

KANT, I. Crítica da razão pura. Trad. Fernando Costa Mattos. 4. ed. Petrópoles: Editora Vozes, 2015.

Crítica da faculdade de julgar. Trad. Fernando Costa Mattos. Petrópoles: Editora Vozes, 2016. 
Mattioli, W.

KEUTEL, O. Über die Zweckmäßigkeit in der Natur bei Schopenhauer. Leipzig: Bruno Zechel, 1897.

LANGBEHN, C. Metaphysik der Erfahrung. Zur Grundlegung einer Philosophie der Rechtfertigung beim frühen Nietzsche. Würzburg: Königshausen \& Neumann, 2005.

LANGE, F. Geschichte des Materialismus und Kritik seiner Bedeutung in der Gegenwart. Iserlohn: J. Baedeker, 1866.

LOPES, R. Ceticismo e vida contemplativa em Nietzsche. Tese de doutorado. Belo Horizonte: UFMG, 2008.

MCLAUGHLIN, P. Kants Kritik der teleologischen Urteilskraft. Bonn: Bouvier Verlag, 1989.

MATTIOLI, W. Inconsciente, intencionalidade e natureza: a dialética morganática entre naturalismo e transcendentalismo na metafísica da vontade de Schopenhauer. In: Revista Voluntas: Estudos sobre Schopenhauer, v. 4, n. 1, p. 66-97, 2013.

O paradoxo das causas finais: Schopenhauer leitor da "Crítica do juízo teleológico". In: Revista de Filosofia Aurora, v. 30, n. 49, p. 205-235, 2018.

MALTER, R. Arthur Schopenhauer. Transzendentalphilosophie und Metaphysik des Willens. Stuttgart - Bad Cannstatt: Frommann-Holzboog, 1991.

Schopenhauers Transzendentalismus. In: Midwest Studies in Philosophy, 8, p. 433-455, 1983.

MILLER, E. Nietzsche on Individuation and Purposiveness in Nature. In: PEARSON, K. A. (ed.) A Companion to Nietzsche. Oxford: Blackwell Publishing, 2006, pp. 58-75.

NIETZSCHE, F. Sämtliche Werke. Kritische Studienausgabe (KSA). Herausgegeben von Giorgio Colli und Mazzino Montinari. 15 Bände. Berlin: Walter de Gruyter, 1999.

Werke. Kritische Gesamtausgabe (KGW). Herausgegeben von Giorgio Colli und Mazzino Montinari. Berlin. New York: Walter de Gruyter, 1995.

Sämtliche Briefe. Kritische Gesamtausgabe (KGB). Herausgegeben von G. Colli und M. Montinari. 8 Bände. Berlin. New York: Walter de Gruyter, 1986.

118 | Cad. Nietzsche, Guarulhos/Porto Seguro, v.39, n.3, p. 77-119, setembro/dezembro, 2018. 
A questão da teleologia nos apontamentos do jovem Nietzsche: Zu...

RICHARDSON, J. Nietzsche’s System. New York/Oxford: Oxford University Press, 1996.

SCHLÜPMANN, H. Friedrich Nietzsches ästhetische Opposition. Der Zusammenhang von Sprache, Natur und Kultur in seinen Schriften 1869-1876. Stuttgart: J. B. Metzlersche Verlagsbuchhandlung, 1977.

SCHMIDT, A. Schopenhauer und der Materialismus. In: Schopenhauer-Jahrbuch, 58, pp. IX-XLVIII, 1977.

SCHOPENHAUER, A. Sämtliche Werke. Hrsg. v. Paul Deussen. München: Piper Verlag, 1911-1926. (Werke auf CD-ROM: Schopenhauer im Kontext).

O mundo como vontade e como representação. Tomos I e II. Trad. Jair Barboza. São Paulo: Editora Unesp, 2005 / 2015.

Sobre a vontade na natureza. Trad. Gabriel Valladão Silva. Porto Alegre: L\&PM, 2013.

SOLIES, D. Nietzsche und die Lebenswissenschaften. In: HELLER, L.; HEIT, H. (ed.) Handbuch Nietzsche und die Wissenschaften. Natur-, geistes- und sozialwissenschaftliche Kontexte. Berlin / Boston: Walter de Gruyter, 2014, p. 107-118.

SOLOMON, R. Nietzsche on Fatalism and "Free Will". In: The Journal of Nietzsche Studies, n. 23, p. 63-87, 2002.

STACK, G. Lange and Nietzsche. Berlin. New York: Walter de Gruyter, 1983.

SWIFT, P. Becoming Nietzsche: Early Reflections on Democritus, Schopenhauer, and Kant. New York / Oxford: Lexington Books, 2005.

TOSCAnO, A. The Method of Nature, the Crises of Critique. The Problem of Individuation in Nietzsche's 1867/1868 Notebooks. In: Pli: The Warwick Journal of Philosophy, n. 11, pp. 36-61, 2001.

The Theatre of Production. Philosophy and Individuation between Kant and Deleuze. New York: Palgrave MacMillan, 2006.

Artigo recebido para publicação em 23/03/2018.

Artigo aceito para publicação em 22/06/2018.

Cad. Nietzsche, Guarulhos/Porto Seguro, v.39, n.3, p. 77-119, setembro/dezembro, 2018. 